\title{
International Top Managers on Corporate Boards: Dissimilarity and Tenure
}

\section{Stefan Schmid $^{1}$ D $\cdot$ Simon Mitterreiter ${ }^{1}$}

Received: 23 September 2019 / Revised: 16 October 2020 / Accepted: 26 October 2020 / Published online: 18 December 2020

(C) The Author(s) 2020

\begin{abstract}
The number of top managers with foreign nationality and of top managers with international work experience on corporate boards has increased over the last decades. In business and management literature, the common understanding is that board diversity and international work experience for board members go hand in hand with numerous positive consequences for MNCs. But how does dissimilarity in nationality and in international work experience affect a top manager and his or her tenure on the board? Drawing on interpersonal attraction research and analyzing 149 management board members from German DAX-30 firms, we find empirical evidence that dissimilarity in nationality and in international work experience have a negative association with tenure. Based on social capital theory, we also suggest that the nexus between a top manager with an international background and his or her tenure is moderated by 'firm insidership'. Our data confirm that having work experience in a firm before being appointed to its board is indeed linked to longer tenure but does not alleviate the disadvantages of being international. In sum, the resulting implication of our research is that, contrary to widely accepted scholarly opinions, a top manager's international background may also have detrimental effects-in our case negative effects on tenure.
\end{abstract}

Keywords International top managers · International work experience $\cdot$ In-house work experience $\cdot$ Nationality $\cdot$ Similarity-attraction paradigm $\cdot$ Tenure

Stefan Schmid

sschmid@escp.eu

1 ESCP Business School, Berlin, Berlin, Germany 


\section{Introduction}

Top management research has expanded considerably over the last decades (e.g., Cannella et al. 2008; Carpenter et al. 2001; Koch et al. 2017; Lovelace et al. 2018; Menz 2012). However, with some exceptions, one characteristic of top managers, and in particular of board members, has received relatively scant attention: tenure (Hambrick and Fukutomi 1991). While prior research has identified some factors that influence board member tenure, such as firm performance or firm size (Ballinger and Marcel 2010; Berns and Klarner 2017; Finkelstein et al. 2009; Fredrickson et al. 1988; Kesner and Sebora 1994; Mietzner et al. 2017), many antecedents of tenure are still poorly explored and understood-in particular antecedents at the level of the individual, such as demographic characteristics of top managers. ${ }^{1}$

Prior literature has stressed that Multinational Corporations (MNCs) benefit from international top managers (Greve et al. 2015; Hamori and Koyuncu 2011; Ruigrok et al. 2013). It has been repeatedly claimed that top managers who are international themselves, or who have international work experience, can cope better with the complexities that arise from the challenges of doing business across borders (Athanassiou and Roth 2006; Carpenter et al. 2004; Schmid and Dauth 2014). It has also been stated that both their mindset and their experience make international managers better prepared in this regard (Jiang et al. 2018; Kedia and Mukherji 1999; Story et al. 2014). International Business (IB) and International Management (IM) literature, along with upper echelons and corporate governance literature, has already investigated positive outcomes of board internationalization, such as higher innovation, better strategic choices, and stronger MNC performance. In this context, literature often called for further increasing board internationalization, so as to reinforce the positive effects of diversity at the firm-level (e.g., Cannella et al. 2008; Chanland and Murphy 2018; Nielsen and Nielsen 2013; Thams et al. 2018).

However, is having a foreign passport or international work experience also beneficial for an individual's tenure on the board? While there is empirical evidence that international top managers provide firms with important assets (Khanna and Palepu 2004; Nielsen 2009), this may come at the expense of detrimental outcomes at the individual level. Through the present study, we ask whether an individual's foreign passport and international work experience have an influence on tenure on the board. The consulting firm 'Strategy\&' recently reported that, in general, tenure of MNCs' top managers has decreased over the last few years (Strategy\& 2016). The question arises as to whether this is particularly true for top executives with a foreign nationality and whether a top

\footnotetext{
1 The tenure of top managers or top management teams has often been conceptualized as an independent variable influencing other outcomes, such as strategic persistence (e.g., Finkelstein and Hambrick 1990), strategic change (e.g., Wiersema and Bantel 1992), organizational success and failure (e.g., Schwenk 1993), or firm performance in general (e.g., Huang and Hilary 2018).
} 
manager's international work experience also impacts tenure (Die Welt 2017; Financial Times 2012; The New York Times 2014).

Studying the relationship between the international background of the individual and his or her tenure is relevant from both a firm perspective and an individual perspective: at the MNC level, recruiting and integrating board members is not only a very complex process, but is also associated with significant cost (Nadler 2016). While we do not claim that longer tenure is always better than short tenure, there is no doubt that, with some exceptions, short tenures of top managers and high turnover rates for top managers are usually not intended by decision-making bodies. This applies in particular to executive directors or inside directors in one-tier corporate governance systems and to management board members in two-tier corporate governance systems. In general, high turnover is associated with negative effects on organizational functioning (Reiche 2009). For instance, executive turnover often not only leads to disturbance and instability in upper echelons (Ballinger and Marcel 2010), but also results in organizational discontinuity (Gjerløv-Juel 2019) or negative communication by media (Bilgili 2017). At the level of the individual, having short tenure may be desired by those individuals who opt for a boundaryless career and who actively look for 'self-directed' careers without spending too much time within one organization (Arthur and Rousseau 1996; Wang and Wanberg 2017). However, short tenure may often also lead to negative consequences for top managers. Examples include disruption to career development (Ward et al. 1995) or lower compensation as a result of having to accept inferior positions (Fee and Hadlock 2004).

To investigate the association between a top manager's internationality and board tenure, we rely on interpersonal attraction research and the similarity-attraction paradigm. We use a sample of management board members from German DAX30 firms. The results of our regression analysis support our theoretical reasoning, thereby demonstrating a negative relationship between top manager internationality and tenure on a board. Based on the social capital perspective, we also reveal that in-house work experience prior to being appointed to the management board is positively related to tenure. However, with our empirical data, we identify no moderation effect of in-house work experience on the negative relationship between top managers' internationality and tenure.

Appointing dissimilar board members may follow the idea of bringing diversity into the board room, with dissimilar board members deliberately having the role to question established views and routines. However, as management board members in the German corporate governance setting have an executive management role (similar to executive directors or inside directors in one-tier corporate governance settings), they are usually expected to have considerable tenure. This allows them to (be able to) shape the firm's future development (Du Plessis et al. 2015; Hopt and Leyens 2004; Kaczmarek et al. 2012). Since the role of supervisory board members (similar to non-executive or outside directors in one-tier corporate governance settings), is rather the monitoring one (Clarke 2017; Mallin 2018), it is desirable that some supervisory board members deliberately have short tenure, bringing in new and fresh perspectives as well as challenging the opinion of management board 
members. This explains why our study focuses on the tenure of management board members and not on the tenure of supervisory board members within firms' top management.

What contributions does our study make to literature and managerial practice? First, by building upon interpersonal attraction research and the similarity-attraction paradigm, we provide theoretical reasoning for a negative relationship between a top manager's internationality and his or her board tenure. We argue that top managers on the board who are different from their peers may encounter problems and situations which shorten their tenure. While existing studies in the IB and IM field have already shown that 'being different' matters, e.g., for entry mode choices (Nielsen and Nielsen 2011), we apply the dissimilarity discussion to the level of MNC top managers and the consequences for their tenure on the board. Second, we empirically demonstrate that being a foreigner or showing deviation from the typical international work experience on the respective board shorten tenure on the board. Hence, we add to the scant literature of board tenure's antecedents at the individual level. To date, albeit with rare exceptions (e.g., Daily et al. 2000; Godthelp and Glunk 2003; Wagner et al. 1984), research has mostly provided evidence of antecedents at the organizational level, such as organizational performance. However, as some scholars have rightly pointed out, board tenure is also determined by factors at the individual level (Cannella and Monroe 1997). Third, with our paper, we consider the effect that in-house work experience (gained prior to being appointed to the board) has on tenure. We provide empirical evidence that longer in-house work experience is beneficial for the individual top manager's tenure. However, we cannot confirm the alleviating moderation effect on the negative relationship between internationality and tenure. Ultimately, through the results of this study, we call for a more nuanced understanding of the consequences of internationality at the individual level. We also complement prior research, which has often identified positive outcomes of internationality for both the individual and the firm.

\section{Theory and Hypotheses}

\subsection{Theory}

To address our main research question, we build on interpersonal attraction research and the similarity-attraction paradigm. Top managers who sit on a management board are part of a group, namely, the management board, and as with any other group, individuals inside of the board relate to each other (Fitness et al. 2007; Thomsen and Conyon 2012). Within a management board, individuals can feel more or less attracted towards others. Attraction has been a subject of investigation in interpersonal attraction research for many decades (Blau 1960; Lott and Lott 1965). In this vein of research, 'attractiveness' refers to the possession of desirable qualities by an individual that evoke positive affective evaluations in others (Byrne and Griffitt 1973; Klohnen and Luo 2003). Similarity indicates a conceptual proposition in which increased 
resemblance between individuals results in increased attraction, which is also due to homophily (Holgersson 2013; Lazarsfeld and Merton 1954; McPherson et al. 2001). Individuals who display specific characteristics or behaviors (e.g., values, beliefs, skills and practices) deemed similar or valuable by an observer usually evoke positive perceptions. Hence, these individuals become attractive in the observer's eyes (Berscheid and Walster 1969; Montoya and Horton 2012). According to interpersonal attraction theory, interaction with similar people is usually considered more effective and enjoyable, because congruence in characteristics produces credibility, reliability, and trustworthiness (Zhu and Westphal 2014). The similarity-attraction effect has turned out to be evident in numerous settings, populations, contexts, and cultures (e.g., Byrne 1997; Lydon et al. 1988; McPherson et al. 2001; Murnieks et al. 2011).

Prior literature in the top management field has already made use of the similarity-attraction paradigm. For instance, Zajac and Westphal (1996) suggest that board members and CEOs tend to select successors similar to them. By relying on US samples of Fortune/Forbes 500 firms, Westphal and Milton (2000) and Westphal and Zajac (1995) demonstrate that homophilous preferences are important criteria in the appointment of board members. Kaczmarek et al. (2012) find that the strong presence of females and non-British nationals on nomination committees of British boards has an impact on board diversity and nationality diversity. Focusing on Chief Human Resource Officers (CHROs) in France, Germany, and the UK, Doms and zu Knyphausen-Aufseß (2014) show that similarity in incumbent top management team (TMT) demographics holds significant explanatory power for new appointees' origins. Drawing on an Indian sample, Damaraju and Makhija (2018) reveal that social proximity in terms of caste and religion influences CEO selection. Investigating executive appointments at large European firms, Georgakakis et al. (2018) conclude that firms are more likely to appoint socio-demographically dissimilar executives through internal promotion; in contrast, external hires are more likely to resemble incumbent top managers. By relying on similarity-attraction theory, McDonald et al. (2018) demonstrate how the appointment of a female or a racial minority CEO affects helping behavior of white male top managers.

While the aforementioned studies argue that similarity in demographic characteristics has an effect on appointments to boards or specific top management positions, other studies investigate the importance of similarity with regard to behavioral integration within top management teams. Simsek et al. (2005), for instance, reveal that similarities in personal characteristics, e.g., education or functional background, favor behavioral integration within TMTs. Similarity also affects compensation; Fiss (2006), for instance, provides evidence that social similarity (e.g., levels of education) between the CEO and the board chair is positively associated with CEOs' compensation. Hwang and Kim (2009) suggest that directors of Fortune 100 firms who share the same qualities or experiences as the CEO receive higher compensation than their dissimilar peers. Hilger et al. (2013) find that similarities between the CEO and other TMT members with respect to age or field of study, inter alia, decrease the likelihood of top manager turnover. 
In this paper, we argue that similarity not only influences appointment to a board, integration, compensation, the helping behavior of top managers and the probability of turnover, but also top managers' tenure on a board. We propose that similarity in personal characteristics can act as a predictor of an individual's longer tenure on a board, whereas dissimilarity in personal characteristics is a predictor of shorter board tenure. ${ }^{2}$ In doing so, we provide novel insights and show that similarity and dissimilarity also have an impact during subsequent stages of a top manager's career.

\subsection{Hypotheses}

Despite some recent developments in board internationalization, boards in most countries are still mainly staffed by board members with the same nationality as the firm (see, for instance, Katmon et al. 2017; Schmid and Dauth 2012; Schmid et al. 2015; Van Veen and Marsman 2008). Consequently, international top managers are often still in the minority in this setting. Based on interpersonal attraction research and the similarity-attraction paradigm, we claim that top managers with a foreign nationality are dissimilar from their (non-international) peers on a board. Growing up in another country shapes fundamental values, beliefs, attitudes, and cognitions of top managers in such a unique way that they have an enduring influence on behavior (Carpenter et al. 2001; Nielsen and Nielsen 2010). It has already been shown that nationality is an important part of a top manager's international background (Hambrick et al. 1998; Nielsen 2010). Having been raised abroad affects a person in terms of values, norms, attitudes, cognitive schemata, and demeanor, inter alia (Hambrick et al. 1998; Hofstede et al. 2010; House et al. 2004). By integrating Byrne's (1971) reinforcement model of the similarity effect, we suggest that, during their work on a board, top managers, like any other individuals, favor stimuli that reinforce their logic and consistency. This assumption is rooted in cognitive dissonance theory, which stresses that individuals possess a fundamental need for a logical and consistent view of the world (Boone et al. 2006; Festinger 1957; Montoya and Horton 2012). The reinforcement model suggests that individuals who are similar in their values, norms, beliefs, and attitudes strengthen each other when it comes to interpreting situations in the same way, interacting, or making decisions, since they share the same view of the world (Byrne et al. 1973; Clore and Gormly 1974; Montoya and Horton 2012). By contrast, top managers who are dissimilar in terms of values, norms, beliefs, and attitudes provoke inconsistency, which may be associated with anxiety or confusion. Ultimately, this may lead to a lack of attraction, or even repulsion (Abt and zu Knyphausen-Aufseß 2017; McCroskey et al. 1974).

We argue not only that international board members differ from non-international ones, but also that dissimilarity in personal characteristics has consequences. Due to a lack of reinforcing logic and consistency, board interaction between top managers

\footnotetext{
${ }^{2}$ While we can partially build on previous work by Hilger et al. (2013) and Wagner et al. (1984), who analyzed the effect of similarity and dissimilarity in age, time of entry or field of study on board turnover, our focus is on similarity and dissimilarity in nationality and international experience and the consequences on tenure.
} 
with differences in terms of values, norms, beliefs and attitudes may be considered less effective because of decreased credibility, reliability and trustworthiness (Li et al. 2017; Lott and Lott 1965). For instance, interpersonal dissimilarity makes knowledge-sharing more difficult (Mäkelä et al. 2007). Previous research has shown that another consequence of intergroup dissimilarity is social disintegration (Guillaume et al. 2012; O'Reilly et al. 1989; Zajac and Westphal 1995). Therefore, we conclude that, during the course of their board mandate, disagreement and friction may arise between foreign top managers and their non-foreign peers. Differences may be so strong, in fact, that collaboration between top managers is hindered and that those top managers who are dissimilar, i.e., those with a foreign nationality, may feel confused, unsettled or in some cases even anxious (Montoya and Horton 2012). In the end, this may result in social disintegration of those board members who are dissimilar to their peers (O'Reilly et al. 1989). It can be assumed that, under such conditions, tenures of board mandates decrease for dissimilar board members. Hence, we claim that individuals who are dissimilar may quit their position prematurely, or their board mandate may either be shortened or not be extended. Consequently, we hypothesize the following:

Hypothesis 1a: There is a negative relationship between a top manager's dissimilarity in nationality and his or her tenure on the board.

In addition to a top manager's nationality, we also argue that a top manager's international work experience has an influence on board tenure. In other words, if there is high dissimilarity with respect to international work experience, this may also lead to a short tenure for those top managers who deviate from the average norm on the board. This notion is based on findings that attest dissimilarities in individuals' experiences to negatively impact on behavioral integration and interaction among board members (Milliken and Martins 1996).

We suggest that for most members on a management board, past job-related experiences denote similarities during their professional life (Hwang and Kim 2009). Similar experiences, sometimes even complemented by some personal interaction, may contribute to interpersonal attraction (Collins and Clark 2003). Carpenter et al. (2001) and Rousseau and Parks (1993) state that common experiences of top managers facilitate communication on the board and encourage the building of trust among each other. Simsek et al. (2005) claim that in case of similar experiences collaborative work in top management teams is more likely. Davidson et al. (2006) argue that shared experiences of board members are a basis for a sound relationship on the board. Hence, board members with similar experience in the home country acquire deeper information about doing business in the home country, i.e., countryspecific skills, routines and practices. In contrast, top managers with long and many international assignments have gained experiences different from those of their peers' experiences. As Knight et al. (1999) claim, dissimilarities in terms of top managers' experiences favor interpersonal conflicts in the board room. This is also underlined by Torchia et al. (2015) who find that dissimilar backgrounds in terms of board members' experiences and skills lead to cognitive conflicts in the board room. 
Therefore, we expect that the lack of mutual experiences may cause disagreement and friction, as top managers equipped with international work experience (and often very diverse experiences) lack shared skills, routines and practices. In other words, top managers with high levels of international work experience who deviate strongly from the average norm on the board are (highly) dissimilar to their counterparts with low(er) levels of international work experience. Likewise, top managers with no international work experience or with levels of international work experience far lower than the average on the board, cannot benefit from the same context of shared international knowledge and skills, for instance about how to do business abroad. Again dissimilarity may end in fragmented understanding and disharmony, which in turn may even result in social disintegration. As such, it can be assumed that this may shorten the tenure of those board members who are dissimilar to the rest of the board. Hence, we claim that individuals who are dissimilar may quit their position prematurely, or their board mandate may either be shortened or may not be extended. Consequently, we hypothesize the following:

Hypothesis 1b: There is a negative relationship between a top manager's dissimilarity in international work experience and his or her tenure on the board.

Tenure on the board may also be contingent on additional characteristics of one's career pattern before entering a board. Scholars suggest that work experience inside the firm (before serving on the board) may have effects other than work experience gained in other firms (Baruch et al. 2013; Grühn et al. 2017; Hamori and Koyuncu 2011). In academic literature on (top) managers' careers, social capital theory has been used to explain outcomes of individual vocational behavior, such as in-house work experience (Hamori et al. 2009; Hamori and Koyuncu 2011; Mäkelä and Suutari 2009). Whereas prior studies have shown that social capital can have some detrimental consequences at board and firm-level, such as, insufficient transparency in decision-making in the board room or shortcomings in monitoring (e.g., Stevenson and Reddin 2009; Westphal 1999), most research stresses the benefits social capital can have. By investigating in-house work experience through a social capital lens, we suggest that such experience may have alleviating effects on the negative association between dissimilarity of top managers on the one hand and board tenure on the other hand. In other words: while we use interpersonal attraction research and the similarity-attraction paradigm to establish our main hypotheses, social capital theory helps us argue why in-house work experience acts as a moderator in our main relationships.

Prior research has shown that 'insiders', i.e., individuals who spent a considerable part of their career in the firm before being appointed as a member of the board, have already established social capital (Dickmann 2017; McEvoy and Buller 2013). Such capital, salient in relationships and ties, for instance, with peers, superiors or subordinates, provides them with information and support to perform well in their jobs (Bower 2007; Chung et al. 1987; Davoine and Ravasi 2013). Furthermore, internally appointed board members are more familiar with the firm's decisionmaking processes and its specific routines and practices (Balsmeier and Buchwald 
2015; Datta and Guthrie 1994; Gupta 1984). For instance, Hambrick and Fukutomi (1991) argue that internally recruited top managers internalize corporate norms faster than outsiders. Moreover, Hamori and Kakarika (2009) even state that insiders are more likely to be promoted to upper echelons, due to prior interaction with the board of directors or with senior executives. As board members with in-house work experience may have established social capital (both in foreign entities and/or in firm's headquarters), we suggest that they are more capable to bridge dissimilarities compared to board members recruited externally (Crossland et al. 2014; Koch et al. 2017). By accumulating social capital, individuals homogenize while being involved in daily business, decision-making processes, and applying shared routines (Bidwell 2011; Lepak and Snell 1999; Shen and Cannella 2002). Furthermore, they are familiar with internal communication patterns and interaction styles and may also adapt the specific 'habitus' that is frequently shared by national corporate elites. Top managers with in-house work experience show behaviors and dispositions considered normative in these circles, corresponding to the expectations by their peers on the board (Hambrick et al. 1998; Nielsen and Nielsen 2013; Kish-Gephart and Campbell 2015). Thus, we propose that in-house work experience has a direct effect: in-house work experience which comes along the considerable accumulation of social capital gained prior to a board appointment positively influences top managers' tenure on the board. Moreover, we advocate that in-house work experience and hence the possession of social capital, also has an interaction effect. It alleviates the negative association between dissimilarity in terms of nationality and international work experience and board tenure. Having established relationships and ties with peers and equipped with firm-specific practices and routines, dissimilar top managers with in-house work experience may be able to limit disagreement, disharmony and consequently conflicts and frictions during their board mandate (Balsmeier and Buchwald 2015; Dickmann 2017), since they have assimilated by integrating into networks with colleagues and by applying shared routines and practices. It can be assumed that shorter tenures are less prevalent under conditions of having worked in the focal firm prior to the board appointment - and thus having built up high levels of social capital. This results in the following hypotheses:

Hypothesis 2a: A top manager's in-house work experience moderates the relationship between a top manager's dissimilarity in nationality and his or her tenure on the board in such a way that the negative relationship will be attenuated in the case of higher in-house work experience prior to the board appointment.

Hypothesis 2b: A top manager's in-house work experience moderates the relationship between a top manager's dissimilarity in international work experience and his or her tenure on the board in such a way that the negative relationship will be attenuated in the case of higher in-house work experience prior to the board appointment. 


\section{Sample and Methodology}

\subsection{Sample}

Our empirical study is based on a sample of management board members of German MNCs. We chose MNCs listed on Germany's DAX, a stock market index consisting of the 30 major firms according to market capitalization. In order to acquire a sample of top managers having completed their board tenure, we needed to take a reference date in the past. We opted for December 312005 and started by identifying all management board members in Germany's DAX 30 firms at the end of 2005. In a next step, we analyzed the careers of these management board members from the moment of entering the job market until leaving the management board. Selecting this specific sample was motivated by three major reasons. First, as German DAX firms depend heavily on foreign trade and foreign direct investment (FDI), it can be assumed that firms have top managers from foreign countries as well as top managers with international work experience on their board. Second, because DAX firms (are required to) disclose extensive annual reports, the chance of obtaining relevant demographic data for the respective top managers from the reports is very high (Oehmichen et al. 2017). Usually, large, public firms provide their stakeholders with exhaustive information on top managers' CVs, for instance, in their annual reports. Third, as corporate governance systems around the world are still countryspecific and career paths to some extent are also culturally and nationally bound (Davoine and Ravasi 2013; Thomsen and Conyon 2012), a single-country study has advantages over a multi-country study (see also, for instance, Fiss 2006; Fiss and Zajac 2004; Oesterle et al. 2016). While the German corporate governance system is a two-tier system, we decided to focus on the tenure of management board members (and not on the tenure of supervisory board members). The tenure of supervisory members follows very different rules, i.e., a short tenure is actually desirable, to make sure that (some) supervisory members can fulfill the tasks of monitoring and challenging the management board's decisions and actions (Thomsen and Conyon 2012).

At the end of 2005, 187 managers served on the management boards of the 30 DAX firms (which leads to a management board size of 6.23 on average). For all 187 managers, we conducted an in-depth analysis of their careers to obtain all relevant demographic and professional data, covering the entire career from their first job until retirement from the management board. By relying on CVs and other bibliographic data (instead of interviews or surveys, for instance), we followed an approach that is very typical in upper echelons research (e.g., Hambrick and Quigley 2014; Nielsen 2010; Oxelheim et al. 2013; Schmid and Altfeld 2018). To collect data, we built on a broad range of sources, such as CVs included in firms' annual reports, information on corporate websites and direct enquiries from investor relations departments, as well as information from top managers' offices. We also included research on compendia such as 'Who's Who' to complete our data. From the 187 cases, we had to exclude 14 cases due to missing data, and another four cases because the top managers were still in office as of December 312017 (and hence they had not ended their tenure). 
To ensure no distortion in our results and to isolate our desired effect, we followed the recommendation of Conyon and Florou (2002), Flickinger et al. (2016) and Zhang (2008), who previously argued that all tenures that had ended due to extraordinary reasons should be eliminated. These extraordinary reasons are (1) illness, inability to work due to disability and death, (2) firm-specific retirement ages, and (3) change of control (i.e., mergers and acquisitions and the abolition of management board mandates). We conducted an analysis of corporate press releases that were disclosed when the respective top manager left the management board. To this end, we used the approach suggested by Flickinger et al. (2016) and searched for key words indicating that tenure had ended for one of the aforementioned reasons. This approach resulted in the exclusion of another 20 cases and left us with a final sample of 149 top managers. Out of the 149 top managers, 123 are German and 26 are of foreign nationality (from Australia, Austria, Canada, Colombia, Denmark, Israel, Malaysia, Namibia, The Netherlands, New Zealand, Sweden Switzerland, the UK and the USA, i.e., 14 different countries). With regard to international work experience, 81 of our 149 top managers have international work experience, while 68 do not. The 81 top managers with international work experience gained this from 41 different countries (the most prominent countries being the USA, the UK, Brazil, and Switzerland). In total, we cover 149 top managers with 5,251 career years (35 career years on average). Although the final sample size of 149 top managers appears low, it corresponds to the sample size in other publications in the upper echelons field (e.g., Georgakakis et al. 2016; Koch et al. 2017; Shen and Cannella 2003; Tian et al. 2011).

\subsection{Independent Variable}

To test our hypotheses, we operationalized top managers' internationality in two different ways. First, for hypothesis 1a, our independent variable is operationalized as a dummy variable (with $0=$ German, $1=$ Foreign). Second, with regard to hypothesis $1 \mathrm{~b}$, we measured international work experience as the number of years of full-time work experience an individual spent outside the respective home country.

To calculate dissimilarity in terms of nationality, we relied on Tröster and Van Knippenberg (2012). We took the square root of the number of board members with a different nationality from the focal top manager nationality and divided this value by the total number of top managers on the respective board. ${ }^{3}$ To calculate dissimilarity in international work experience, we start by determining, for each management board in our sample, the average number of years of international work experience the management board members have. To be precise, for all individuals in our sample, we summed the years of international work experience of each top manager on the respective board and divided this value by the total number of top managers on the corresponding board (a). Then, we computed the deviation in years of

\footnotetext{
3 Scores were computed so that larger numbers meant that the focal top manager was more dissimilar to his or her fellows on the management board. In addition, in this analysis (Model 2 in Table 2), a score of 0 indicates that the focal individual is German, and every member of the management board is also German. We suggest that cases with a score of 0 may bias our overall results. Hence, we created a dummy variable to minimize potential distortion for Model 2 in Table 2.
} 
international work experience of the focal individual top manager and the respective board (b). Dissimilarity constitutes the difference between (a) and (b), taking into account both positive and negative deviations. ${ }^{4}$

\subsection{Dependent Variable}

For our dependent variable, i.e., board tenure, we considered the number of years the individual spent on the board of the focal firm from his or her first appointment until retirement/dismissal from the board (see also, Brown et al. 2017; Henderson et al. 2006; Hill and Phan 1991; Simsek 2007; Veltrop et al. 2018). In a few cases, top managers had several responsibilities over time on the management board (e.g., first $\mathrm{CFO}$, then $\mathrm{CEO}$ ); in these instances, we added the years in different functions, since we are interested in the overall length of board tenure.

\subsection{Moderator Variable}

Based on our theoretical reasoning, we assume that in-house work experience moderates the relationship between top managers' internationality and board tenure. Going beyond the established operationalization of insidership with a dummy variable [ $1=$ Yes, $0=$ No; e.g., Cannella and Shen (2001)], we operationalized in-house work experience as the total number of years the top manager had worked for the focal firm before having been appointed to the management board (see, for instance, Georgakakis et al. 2016; Karaevli 2007; Karaevli and Zajac 2013).

\subsection{Control Variables}

We control for factors that influence board tenure at the individual, firm and industry level. As previous studies concluded that older managers show a higher tendency to have shorter board tenure, we controlled for age at the time of being appointed to the management board (Finkelstein et al. 2009). Although prior research has pointed out possible gender disparities in top managers' board tenure (Elsaid and Ursel 2018; Main and Gregory-Smith 2018), we did not control for gender, as our sample consisted only of males (which, as a side note, is striking, since it shows that in 2005, management boards in the DAX-30 companies were fully male-dominated, with one female management board member only). Moreover, we investigated the prior career paths of our executives and controlled for past management board positions of the respective top manager with a dummy variable. In other words, we wanted to check whether an individual top manager had already served on the management board of other DAX firms, before being appointed to the board of the focal DAX-30 firm.

\footnotetext{
4 Scores were computed so that (large) positive numbers meant that the focal top manager is (very) dissimilar in terms of high levels of international work experience, compared to the average norm, i.e., the average work experience the fellow members in the management board show. (Large) negative numbers indicate that the focal top manager is (very) dissimilar in terms of a low level of international work experience compared to the average norm on the board.
} 
We also checked for the specific function the management board member had, so as to control for the influence of functional responsibilities on the management board (Menz 2012). ${ }^{5}$ Similar to previous research, we differentiated between input functions (e.g., purchasing), throughput functions (e.g., operations), and output functions (e.g., sales), as well as strategy functions (e.g., CEO) (Datta and Rajagopalan 1998; Herrmann and Datta 2002). ${ }^{6}$ We then created a dummy variable for each function.

With regard to firm characteristics, a vast body of research states that firm performance is a significant antecedent of board tenure (e.g., Arthaud-Day et al. 2006; Coughlan and Schmidt 1985; Georgakakis and Ruigrok 2017; Huson et al. 2001; Kaplan and Minton 2012). In most cases, weak performance leads to shorter tenure. As prior studies have shown that both accounting-based performance and marketbased performance can influence the tenure of a board member, we controlled for both accounting and stock performance. The former is calculated as the average return on equity (ROE) over the last three years before the tenure of the respective individual ended, and the latter is computed as the average percentage change in the stock price over the last three years before the tenure ended (Jenter and Kanaan 2015; Kish-Gephart and Campbell 2015; Peng et al. 2015). Additionally, we controlled for firm size (the year before the respective tenure ended) as the logarithm of total sales (Carpenter et al. 2001; Fernandes et al. 2013), because authoritative literature such as Finkelstein et al. (2009) suggested that there is an association between firm size and the duration of appointments on a management board. Furthermore, as individuals on larger boards tend to have shorter tenure, management board size (again, the year before the respective tenure ended) may have an influence on the internationality-tenure nexus for which we also controlled (Murphy 1999).

Finally, prior research has demonstrated that industry may impact top managers' board tenure (Cho and Hambrick 2006). Hence, to account for industry effects, we created dummy variables to indicate industry categories based on firms' one-digit SIC codes (Jenter and Kanaan 2015). Similar to other studies on German DAX-30 firms (e.g., Tuschke et al. 2014), we used categories comprising Consumer Goods, Automotive and Manufacturing, Transportation and Public Utilities, Wholesale Trade, Finance/Insurance and Real Estate, and Services. ${ }^{7}$

\subsection{Analytical Approach}

In our main analysis, i.e., our set of hypotheses $1 \mathrm{a}, 1 \mathrm{~b}, 2 \mathrm{a}$ and $2 \mathrm{~b}$, we applied multiple regression analysis with an OLS estimator to test our hypotheses. This method is

\footnotetext{
${ }^{5}$ In the few cases where a top manager had several responsibilities over time on the management board, we classified the corresponding top manager in the board function for which he or she had his or her longest tenure.

6 In case a top manager had divisional responsibilities during his or her board mandate, we classified this into 'output functions' as we can assume that large parts of his or her responsibilities were connected to output-related tasks such as marketing or sales.

7 With a sample size of $n=149$, the inclusion of 15 control variables and 1 explanatory variable, i.e., in total 16 control and explanatory variables, slightly exceeds Darlington's (1990) rule of thumb suggesting to include $14.9(149 / 10=14.9)$ control and explanatory variables. According to Harris (2001),
} 
appropriate when analyzing a metric-dependent variable such as board tenure (Aiken and West 1991). To test our moderation hypotheses, we added the interaction term inhouse work experience $x$ nationality dissimilarity/international work experience dissimilarity to investigate the moderation effect (Greene 2008). In all regression analyses, we included our control variables to minimize specification bias. All controls were successively added to the regression models before including the independent variable to be tested (Adkins and Hill 2011; Baum 2009; Bernerth and Aguinis 2016).

As for many other studies in top management research, it is challenging to establish causation between a phenomenon (e.g., top manager internationality) and a specific outcome (e.g., board tenure). Unfortunately, an ideal research setting with all relevant data available and a full disclosure of possible correlations between variables is impossible. If, for instance, the predictor variable depends on unobservable factors that correlate with the error term, we may have biased estimates of the effect on the outcome variable. In our case, this would mean that an individual's nationality and his or her international work experience would depend on unobservable factors (which is even more likely for international work experience than for nationality). Consequently, estimates of the effect on tenure would be distorted. A vast body of literature has addressed this endogeneity problem (for recent overviews in the IB/ IM field, see, for instance, Meyer et al. (2017) or Reeb et al. (2012)). We can curb the endogeneity problem in some way by including control variables at the individual, firm and industry levels (Ebbes et al. 2016; Papies et al. 2017), but we admit that, like in many other studies, endogeneity cannot be fully excluded. Reverse causality is not a problem in our setting, as board tenure cannot have an influence on top manager internationality. Both nationality and international work experience (before having been appointed to the board) precede tenure, while tenure cannot have an effect on them. However, while we do not have a reverse causality problem, we cannot entirely solve endogeneity issues. Therefore, we acknowledge that our results, like most results in similar upper echelons settings, should be interpreted with care.

\section{Results}

\subsection{Main Analysis}

Table 1 provides descriptive statistics and correlations. Table 1 reveals that more than $17 \%$ of our top managers have foreign nationality; the average international work experience amounts to approx. 5.3 years, and the average tenure to approx.

\footnotetext{
Footnote 7 (continued)

however, the difference between the sample size and the number of control and explanatory variables should exceed 50. In our case, the difference amounts to $133(149-16=133)$, which corresponds to Harris's (2001) recommendations. Howell's (2012) formula suggests that the sample size should be equal or greater than the number of control and explanatory variables plus 40. Applying this formula to our setting, we reach: $149 \geq 56(16+40)$. Hence, we are able to conclude that given the number of observations $(n=149)$, the number of control and explanatory variables $(n=16)$ in our models is within an acceptable range.
} 


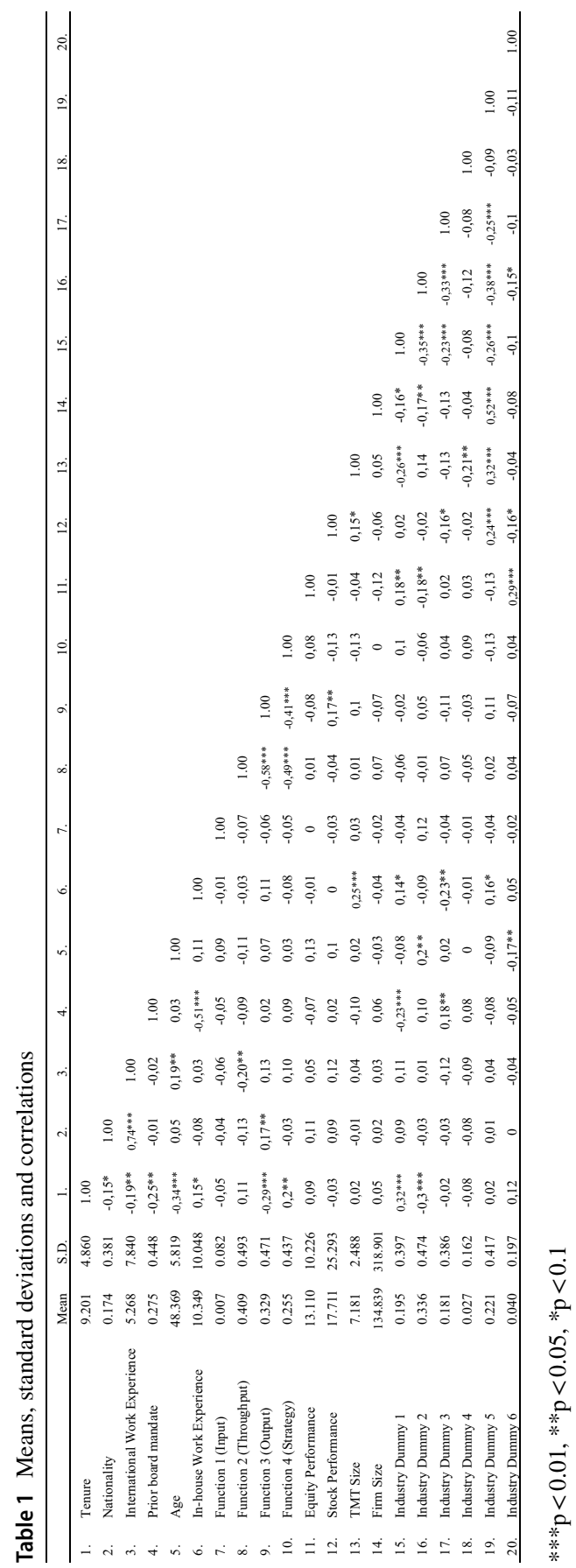


9.2 years. Since there are some significant correlations between our independent variables, we computed variance inflation factors (VIFs). The results show that, in all models, the highest VIF scores are below the cutoff value of 10 (Cohen et al. 2003), which implies that multicollinearity is not an issue.

Table 2 presents the results of the regression analysis. We first entered all control variables in the study (Model 1) before adding the independent variables nationality dissimilarity (Model 2 for testing hypothesis 1a), international work experience dissimilarity (Model 3 for testing hypothesis 1b) and the moderator variable in-house work experience (Model 4 and Model 5 for testing hypotheses $2 \mathrm{a}$ and 2b, respectively) sequentially.

Model 1 represents the baseline model with control and moderator variables only. With respect to these variables, our results confirm various associations previous literature expects with regards to board tenure: at the individual level, tenure can mainly be attributed to top manager's age (significantly negatively related to board tenure at the $\mathrm{p}<0.01$ level). Although not surprising, we find that the older the respective individual at the time of appointment, the shorter the tenure. Prior board experience is also negatively associated with tenure $(-1.88$ at $\mathrm{p}<0.05)$. Top managers who already served on other boards may actively engage in new (board) experiences and therefore do not strive for longer tenure. Being a board member in an output function (such as marketing or sales) also has high explanatory power (significantly negatively related to tenure at the $\mathrm{p}<0.01$ level). Our results are in line with a recent debate that top managers with output function have the highest turnover rate in the C-suite (see, for instance, Harvard Business Review 2017, Korn Ferry 2018). ${ }^{8}$ Finally, with regards to industry effects, we find that serving in the consumer goods industry significantly acts as predictor of longer board tenure $(\mathrm{p}<0.05)$. This echoes prior findings that board members' tenure in industries characterized by rather high stability is longer than board members' tenure in dynamic, volatile industries (e.g., Henderson et al. 2006). ${ }^{9}$

By adding nationality dissimilarity as an independent variable into the regression analysis (Model 2), a negative relationship between top managers' nationality dissimilarity and tenure can be identified $(-4.52$ at $\mathrm{p}<0.05)$. Thus, we find support for hypothesis 1a. To test hypothesis $1 \mathrm{~b}$, we used international work experience dissimilarity as an independent variable (Model 3). Again, a negative relationship between dissimilarity in international work experience and tenure is confirmed by our data $(-0.12$ at $\mathrm{p}<0.05)$. Consequently, we also find support for hypothesis $1 \mathrm{~b}$. To refine our results, we performed a sub-sample analysis (taking into account the upper and lower decile of our sample), differentiating between those top managers who strongly deviate in a positive way and those top managers who strongly deviate

\footnotetext{
${ }^{8}$ To corroborate, we also compared the mean values for tenure and conducted a one-sample t-test which confirmed the differences between top managers with an output function and their colleagues on the board serving on other functions $(\mathrm{p}<0.001)$. The results of the t-test are available from the authors upon request.

9 Again, a mean comparison and the corresponding t-test confirm our regression results $(\mathrm{p}<0.001)$. The results of the t-test are available from the authors upon request.
} 


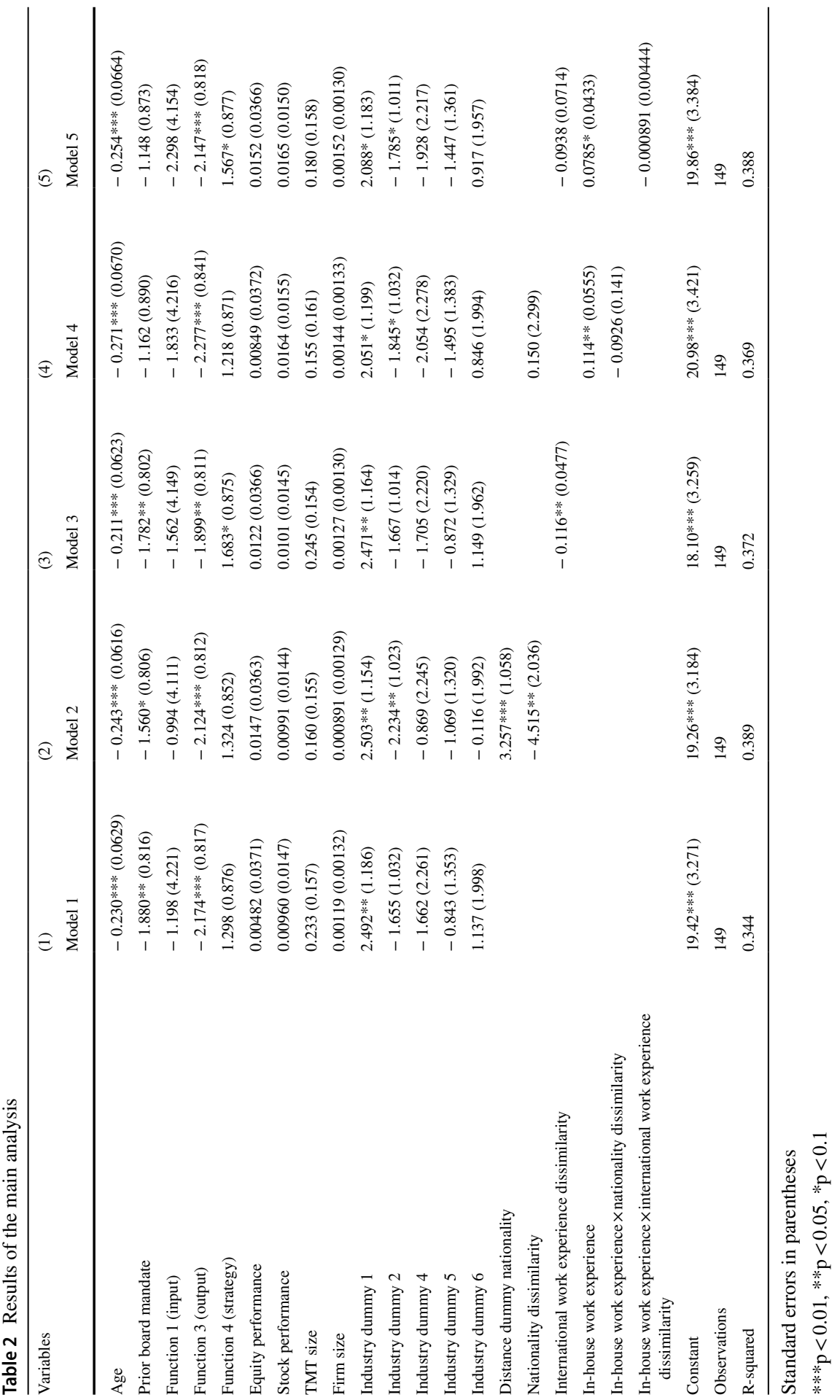


in a negative way from the average norm on the respective board with regard to international work experience. ${ }^{10}$ For the top managers who positively deviate from the average norm, we find a significant negative relationship $(p<0.1)$, whereas for the top managers who negatively deviate from the average norm, we obtained no significant results $(\mathrm{p}>0.1)$.

Model 4 shows the results of the analysis with which we tested our moderation hypotheses $2 \mathrm{a}$. Hypothesis 2 a predicts that in-house work experience has a positive moderating influence on the negative relationship between nationality dissimilarity and tenure. The positive coefficient (0.11) of the moderator variable in-house work experience is significant at $\mathrm{p}<0.05$. The coefficient of nationality dissimilarity is insignificant. The interaction term, i.e., the product of the moderator variable and the independent variable, is insignificant, too, which means that there is no empirical evidence for in-house work experience (prior to the appointment to the management board) to alleviate the negative relationship between nationality dissimilarity and tenure. Hence, our empirical results do not support hypothesis $2 \mathrm{a}$.

Hypothesis $2 \mathrm{~b}$ assumes a positive moderating influence of in-house work experience on the negative relationship between international work experience dissimilarity and tenure. Model 5 presents the results of the analysis: again, the positive coefficient of in-house work experience (0.08) is significant at $\mathrm{p}<0.1$. The negative coefficient of international work experience dissimilarity is insignificant. Again, the interaction term, i.e., the product of the moderator variable and the independent variable, is not significant. Consequently, we do not find empirical support for hypothesis $2 b$.

Although we do not have empirical support for our moderation hypotheses, we still can conclude that top managers, having worked in the focal firm prior to the board appointment (i.e., top managers equipped with in-house work experience), have longer tenure (significant at the $\mathrm{p}<0.05$ level). This underscores our reasoning that in-house work experience matters, albeit in a direct way (e.g., Georgakakis et al. 2016; Hamori and Koyuncu 2011) and not in a moderation way.

\subsection{Robustness Checks}

The negative influence of our predictor on tenure, i.e., dissimilarity in terms of nationality and international work experience, is based on arguments from interpersonal attraction research and the similarity-attraction paradigm. In two robustness checks, we modify our measurement of the dissimilarity of top managers regarding their nationality and international work experience. ${ }^{11}$

Dissimilarity is not just a matter of being a foreigner (or not), or deviating positively or negatively from the average norm of international work experience on the

\footnotetext{
${ }^{10}$ Taking into account the upper and lower decile of a sample results in a relatively low sample size for our sub-analysis.

${ }^{11}$ These robustness checks were carried out following the recommendation of a very helpful reviewer we gladly followed.
} 
respective top manager's board. It may also matter what nationality a foreigner has and which distance exists between the foreigner's home country and the country in which he or she sits on the board, i.e., Germany. The same applies to the question where the management board member has gained his or her international work experience (Hambrick et al. 1998; Schmid and Wurster 2017). We argue that experiences in proximate countries to Germany, such as Austria or Switzerland, differ from experiences in countries which are distant to Germany such as China or India. Taking into account these dissimilarities between countries, we decided to use cultural and linguistic distance measures in our robustness checks (i) and (ii). Not only differences in culture, but also differences in language (and their magnitude) may matter when it comes to ascertaining how dissimilar an individual may be (see also, Cao et al. 2019).

With regard to cultural distance, we relied on the GLOBE study (House et al. 2004) and took Mahalanobis distances between Germany and the country of origin of the respective individual, in order to compute dissimilarity scores for nationality (Berry et al. 2010; Yeganeh 2014). In a similar vein, to calculate dissimilarity scores for international work experience, we took the Mahalanobis distance (Yeganeh 2014) between Germany and each country where the respective top manager had gained international work experience (we weighted each stay abroad with its duration). Following West and Graham (2004, see also, Jimenez et al. 2019), we computed linguistic distances from German to the primary language in the respective country of origin and the country or countries where international work experience was gained, and again, we weighted each stay abroad with its duration (for alternative options on how to calculate linguistic distances, see, for instance, Dow and Karunaratna 2006).

\subsubsection{Robustness Check (i) for Dissimilarity in Nationality}

Model 1 and Model 2 of Table 3 present the results of the first robustness check. Model 1 discloses a significant negative relationship between nationality dissimilarity (in terms of cultural distance) and tenure $(-0.55$ at $\mathrm{p}<0.05)$. With regard to Model 2, our results show that, once more, nationality dissimilarity (now in terms of linguistic distance) is significantly negatively related to board tenure $(-1.18$ at $\mathrm{p}<0.05)$. Hence, our robustness check confirms that dissimilarity in nationality shortens tenure. Thus, the results from the main analyses remain robust when applying cultural and linguistic distances to measure dissimilarity. We can conclude that the higher the cultural distance and linguistic distance between Germany and the country of origin of the respective top manager the shorter the tenure on the board.

\subsubsection{Robustness Check (ii) for Dissimilarity in International Work Experience}

In the main analysis, we analyzed the dissimilarity in international work experience in terms of duration with respect to the average norm on the individual top manager's board. To measure dissimilarity in our robustness check, we use the weighted cultural and linguistic distance between Germany and the country/countries where international work experience was gained. For cultural distance, Model 3 (Table 3) 


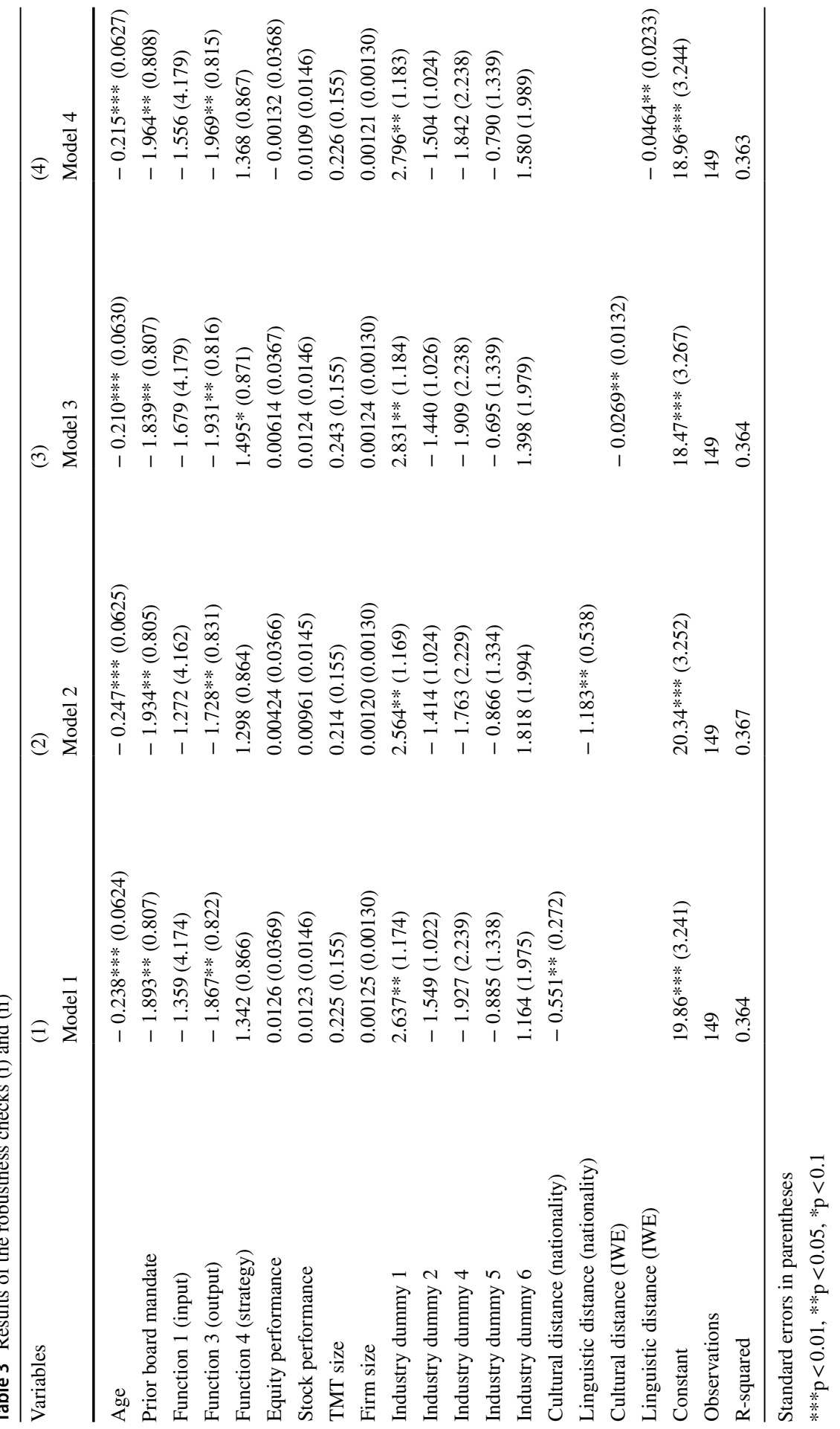


shows that dissimilarity in terms of international work experience is negatively associated with tenure $(-0.03$ at $\mathrm{p}<0.05)$. Likewise, when taking into account linguistic distance, dissimilarity in terms of international work experience discloses a significantly negative relationship with tenure $(-0.05$ at $\mathrm{p}<0.05)$. This shows that our results remain robust and we can therefore confirm our findings from hypothesis $1 \mathrm{~b}$ in the main analysis. We can assume that the higher the cultural distance, and, respectively, the linguistic distance, between Germany and the destination of the assignment(s) where international work experience took place, the more negative the impact on tenure.

In conclusion, the results of robustness checks (i) and (ii) shed light on the underlying mechanisms that are at work if we study the link between internationality and tenure on the board. Our results support our theoretical assumptions that higher dissimilarity in terms of higher cultural and linguistic distance may implicate shorter tenure on the board. In addition, our results also reveal some differences between nationality on the one hand and international work experience on the other hand. Not surprisingly, being culturally and linguistically dissimilar in terms of nationality is even more detrimental for an individual's board tenure than cultural and linguistic dissimilarity in terms of international work experience. Hence, nationality dissimilarity seems to be a stronger predictor of short tenure than dissimilarity with regard to international work experience. In other words, having different values, norms, beliefs and attitudes (Carpenter et al., 2001; Nielsen and Nielsen 2010) has a stronger impact than having dissimilarity in skills, routines and practices resulting from international work experience.

\subsection{Supplementary Analysis}

In a supplementary analysis, we add to the findings of our robustness checks by estimating a multinomial logit regression model with three possible outcomes for a given observation (in our case, nationality dissimilarity and dissimilarity in international work experience in terms of cultural and linguistic distance): short tenure, intermediate tenure and long tenure. According to Allgood and Farrell (2000), we defined 1-3 years of tenure as short tenure, 4-10 years as intermediate tenure and 11 or more years as a long tenure, thereby allowing us to extend the findings of our main analysis. With our main analysis, we are able to show that board tenure (as a time-based measure in years) becomes shorter in case of dissimilarity in nationality and international work experience. With our supplementary analysis, we intend to identify probabilities of serving different lengths of tenure. To do so, after having estimated our log odds, we calculated average marginal effects (AMEs) to allow for better understanding and interpretations of our results (Bowen and Wiersema 2004; Breen et al. 2018; Liao 1994). AMEs reveal the average change in outcome probability when the independent variable increases by one.

With regard to nationality dissimilarity, the results in Table 4 (Model 1) disclose that, in terms of cultural distance (using GLOBE data), significant effects exist when it comes to intermediate tenure: one more unit of cultural distance increases the probability of an intermediate tenure by 6 percentage points $(\mathrm{p}<0.1)$. When it comes to 
Table 4 Results of the supplementary analysis

Multinomial logit regression with average marginal effects (AMEs)

$\begin{array}{lll}\text { Short tenure } & \text { Intermediate tenure } & \text { Long tenure } \\ (1-3 \text { years }) & (4-10 \text { years }) & (\geq 11 \text { years })\end{array}$

Independent variable (nationality dissimilarity), measured with...

Model 1

$\begin{array}{llll}\ldots \text { GLOBE data (Mahalanobis distance) } & 0.01 & 0.06^{*} & -0.07 * * \\ \ldots \text { data on linguistic distance } & 0.07 * * & 0.25^{*} & -0.33^{* *}\end{array}$

Independent variable (dissimilarity in international work experience), measured with...

Model 2

$\begin{array}{llll}\text {.. GLOBE data (Mahalanobis distance) } & 0.0008 & 0.004^{* *} & -0.005^{* *} \\ \ldots \text { data on linguistic distance } & 0.003^{* *} & 0.008^{*} & -0.01^{* *}\end{array}$

$* * * \mathrm{p}<0.01, * * \mathrm{p}<0.05, * \mathrm{p}<0.1$

long tenure, one more unit of cultural distance reduces the probability of long tenure by 7 percentage points $(\mathrm{p}<0.05)$. In terms of linguistic distance, we can conclude that one more unit of linguistic distance increases the probability of serving a short tenure by 7 percentage points $(\mathrm{p}<0.05)$. By contrast, increasing the linguistic distance by one unit reduces the probability of a long tenure by 33 percentage points $(\mathrm{p}<0.05)$. Model 2 presents the results for international work experience dissimilarity, revealing that increasing cultural distance by one unit, i.e., going abroad in a culturally more distant country, increases the probability of serving an intermediate tenure by 0.4 percentage points $(\mathrm{p}<0.05)$, whereas the probability of a long tenure decreases by 0.5 percentage points $(\mathrm{p}<0.05)$. Having a look at the linguistic distance of the countries where individuals have gained their international experience, one more unit of linguistic distance increases the probability of serving a short (intermediate) tenure by 0.3 percentage points at $\mathrm{p}<0.05(0.8$ percentage points at $\mathrm{p}<0.1)$; however, the probability of serving a long tenure decreases by 1 percentage point $(\mathrm{p}<0.05)$. In sum, running a logit model reveals that more dissimilar top managers have a significantly lower probability of serving a 'long' tenure, whereas the probability of serving a 'short' tenure, at least in our sample, is only significant in those models where we use linguistic distance as a dissimilarity measure. Hence, our supplementary analysis elucidates that highly dissimilar top managers are less likely to serve 'long' periods on the board. Furthermore, our supplementary analysis shows that dissimilar top managers (measured via linguistic distance) are more likely to serve a short tenure on the board.

\section{Discussion and Contributions}

\subsection{Discussion}

In our study, we investigate how top managers' internationality is associated with their tenure on the management board. Drawing on interpersonal attraction research and 
the similarity-attraction paradigm, we suggest that high dissimilarity in nationality and international work experience is negatively related to top managers' board tenure.

We find evidence that international top managers who are either foreigners or who deviate in terms of international work experience from the norm on their respective board serve a shorter time on a firm's board. Altogether, dissimilarity in nationality has a stronger impact on tenure compared to dissimilarity in international work experience. It seems that dissimilarity in terms of different values, norms, beliefs, and attitudes is perceived as more salient in day-to-day business than dissimilarity in terms of experiences, which often go hand in hand with different skills, routines and practices acquired through extensive international work experience (Froese et al. 2016; Tenzer et al. 2017). It is interesting to note that in all of our OLS models, higher dissimilarity is associated with shorter tenure as a time-based measure. In our logit models, only dissimilarity measured via linguistic distance is associated with a higher probability of serving a short tenure. ${ }^{12}$ This underscores the importance of language-and hence how possible missing linguistic proficiency in the boardroom (Piekkari et al. 2015) may contribute to short tenure. In contrast, probabilities of serving a long tenure are significantly lower throughout all estimated logit models.

Our findings also mirror prior research on faultlines in the boardroom. Faultlines appear when a group consists of various subgroups that differ in terms of demographic characteristics (Lau and Murnighan 1998; Li and Hambrick 2005; $\mathrm{Ou}$ et al. 2017). Prior research has argued that faultlines within boards, for instance between the CEO and the TMT, may have negative consequences on strategic change or firm performance (see, for instance, Georgakakis et al. 2017; Richard et al. 2019; Van Peteghem et al. 2018). With the present paper, we take a step back and show that dissimilarities in demographic characteristics also create faultlines between the individual top manager and his or her fellows on the board-with negative outcomes for the individual, i.e., a top manager's tenure on the board. Hence, our findings bridge research on faultlines in upper echelons by showing how dissimilarities in demographic characteristics influence individual-level outcomes which subsequently may affect firm-level parameters. Based on our results, we can reasonably assume that dissimilarity in nationality (and in particular nationalities which have a high cultural distance and high linguistic distance) may lead to more faultlines than dissimilarity in international work experience. Interestingly, too much international work experience (compared to the average norm on the board) seems to be detrimental for tenure, while lower levels of international work experience do not seem to reduce tenure.

However, through our empirical study, we could not confirm the moderating effect prior in-house work experience has on the relationship between internationality and tenure. Although social capital theory suggests that previous inhouse work experience contributes to the creation of social capital (which alleviates the negative effects of being dissimilar), it appears that, in our sample at least, international top managers cannot benefit from in-house work experience

\footnotetext{
${ }^{12}$ Once more, 'short tenure' refers to the classification by Allgood and Farrell (2000), i.e., tenure up to 3 years.
} 
prior to their appointment, so as to reduce the negative impact their dissimilarity may have on their tenure. One explanation is that, despite increasing tendencies to internationalize boardrooms (Van Veen 2014), many firms still show an ethnocentric orientation (Michailova et al. 2017). Another explanation is related to individuals rather than to firms. Top managers with an international background may have a desire to move frequently to new positions, and, hence, they do not strive for long tenure in a specific firm. This mirrors recent scholarly discussions on so-called boundaryless careers, stating that some individuals frequently change their job positions across organizations and by doing so, also across different countries (McNulty and De Cieri 2011; Suutari et al. 2012). ${ }^{13}$

\subsection{Contributions}

Our study offers several contributions, the first of which is of a theoretical nature, in that we provide theoretical reasoning for a negative relationship between top managers' internationality and their board tenure. With the similarity-attraction paradigm as a theoretical lens, we argue that similarity and attraction matter not only in appointment decisions (Doms and zu Knyphausen-Aufseß 2014), but also for tenure of top managers. While it has been stated that relational demography approaches (Tsui and O'Reilly 1989) are useful for studying the impact of similarity and dissimilarity on appointment decisions (Westphal and Zajac 1995) or CEO compensation (Fiss 2006), we claim that similarity and dissimilarity also have an impact during subsequent stages of a top manager's career. With our focus on the similarity between an individual (i.e., a top manager) and a group, i.e., the board, we extend composition diversity research and follow a call by Van Knippenberg and Mell (2016) who encouraged more work in the field, in order to bridge individual and team level analyses. By applying interpersonal attraction approaches to firms' upper echelons, we theorize that dissimilarity shortens tenure on the board. Thus, we also act on a suggestion by Cragun et al. (2016), who called to investigate top managers in the context of their peers on the board, in order to argue theoretically why tenure ends.

Second, our study contributes to tenure research by providing new empirical insights into the antecedents of board tenure at the individual level. Having empirical evidence on the factors that influence tenure at the individual level is important for MNCs. One major reason is that a top manager's end of tenure implies a change at the firm's apex, which in turn affects the future direction of the organization and hence is of utmost importance for a firm's strategy, structure, and even culture (Godthelp and Glunk 2003; Hambrick and Mason 1984). Thus far, the majority of studies have focused on antecedents of tenure at the organizational level (e.g., Ballinger and Marcel 2010; Brickley 2003). With rare exceptions (Daily et al. 2000; Godthelp and Glunk 2003; Wagner et al. 1984), prior literature has not analyzed antecedents at the

\footnotetext{
13 We are aware that we are unable to find out whether some of our top managers in the sample are on boundaryless career tracks (or not). We tried to curb this problem by controlling for 'prior board mandates', which may serve as a possible indicator for being on a boundaryless career track.
} 
individual level. We investigate the association between top managers with an international background and tenure. We empirically disclose that board tenure shortens if top managers are dissimilar in terms of nationality and international work experience. As top managers in stock market-oriented firms are appointed by boards or shareholders, this has important implications for corporate governance literature and corporate governance practice: those who are responsible for an appointment, i.e., shareholders in monistic corporate governance systems and supervisory boards in a dualistic corporate governance environment (Monks and Minow 2011; Thomsen and Conyon 2012), should select board member candidates taking multiple dimensions into account. Moreover, local (incumbent) board members should be coached and educated in such a way that they depart from ethnocentric philosophies and accept peers on the board who are dissimilar in terms of nationality and substantial international work experience (Köllen et al. 2020).

Third, our study advances our knowledge about the impact of in-house work experience on the relationship between the internationality of board members and their tenure. Our empirical analyses show that previous in-house work experience (in the firm where an individual holds a mandate on the management board) is beneficial for board tenure. Therefore, we contribute to career literature by showing that in-house work experience is important not only for promotion to top executive ranks (e.g., Agrawal et al. 2006; Hurley et al. 1997), but also for tenure in the C-suite. While a '(life) long in-house career' may currently be seen as undesirable or even as 'boring' by some individuals (Hamori et al. 2015), it still is a predictor of longer tenure. However, our empirical results from the moderation analysis suggest that firm insidership does not alleviate the negative effects of internationality on board tenure. Hence, while firm insidership may be positive for many reasons, such as the development of intra-firm networks or as a faster way to the top (Georgakakis et al. 2016; Hamori and Kakarika 2009; Hamori and Koyuncu 2011), it does not mitigate the negative effect that an international background has on tenure. Since in-house work experience shows no attenuating moderation effect, this has consequences for firms with long-term development plans for future board members from inside the firm. Van Vianen et al. (2018, p. 593) state that "(...) the complexity of contemporary career paths and the more self-determined role of employees in shaping their careers urge changes in traditional organizational career development (...)". For firms that have an international talent pool and use expatriation and repatriation for potential board members of tomorrow, we suggest taking actions to counterbalance the negative effects of dissimilarity in terms of foreign nationality and international work experience. Global talent pools, which are especially designed for (future) top managers, can provide access to networks with senior managers and can be a way of compensating for (too) much internationality (e.g., Collings 2014; Schmid and Wurster 2017; Van Bakel 2019). Moreover, managers working abroad can benefit from experienced mentors in the home country (e.g., Baruch et al. 2017; Carraher et al. 2008; Kraimer et al. 2016), in order to become well-prepared for a stable career in the C-suite.

In summary, academia has so far outlined many benefits of top manager internationality, both at the level of the MNC and at the level of the individual (Nielsen 2010; Piaskowska and Trojanowski 2014). While some studies have already shown 
that internationality can also have mixed effects (Georgakakis et al. 2016; Kaczmarek and Ruigrok 2013; Schmid and Altfeld 2018), our study points to detrimental consequences for tenure at the individual level that should not be neglected-detrimental consequences for tenure. Anticipating the organizational consequences of hiring foreigners or top managers with foreign nationality and considerable international experience (which goes beyond the average norm on the board) seems warranted. Previous research has shown that 'short' tenure induces high costs, both monetary and non-monetary (e.g., Bilgili 2017; Grusky 1963; Oesterle 1999). ${ }^{14}$ These costs include severance packages due to prematurely withdrawing from contracts ('golden handshakes'), lost profits owing to conflicts and frictions on the board, and finally, both the costs of screening new board members and of negotiating new contracts (Nadler 2016). Marcel et al. (2017) take this concept one step further and reveal that 'disruptive' CEO successions, i.e., unexpected terminations of tenure, may be seen as a lapse of governance that, in turn, may threaten the legitimacy of a firm's board and shareholders as well as the firm as such.

\section{Limitations and Further Research}

Our study is subject to some limitations that serve as promising avenues for future research. First, while our dependent variable tenure seems very easy to capture, we should not forget that there are multiple reasons why a board member leaves the management board (Daily and Dalton 1995). However, when board members end their tenure, the 'true' reason is often not obvious-and it is often not communicated by the firm in question (De Fond and Park 1999; Denis and Denis 1995). It is evident that it would be very fruitful also to include the reasons why tenure ends in empirical studies like ours, since the impact of top manager internationality on tenure may be contingent on the reasons why tenure may end. To date, a considerable body of research has examined available data from various sources, such as newspaper articles and press releases, and attempted to further categorize various reasons why tenure ends (e.g., Hilger et al. 2013; Jenter and Kanaan 2015; Oehmichen et al. 2017; Schepker and Barker 2018). In the present study, we tried to curb this problem of not knowing the 'true' reason why our top managers left the board, by following the systematic approach suggested by Flickinger et al. (2016), in order to exclude specific turnover events that risked biasing our research results. Despite this approach, we admit that the 'true' reason behind the turnover event of each top manager is not accounted for herein. Quantitative studies such as the present one will probably never include data on all board members and the 'true' reasons for the ending of board memberships (see, for instance, Mobbs 2013). Hence, we suggest that

\footnotetext{
14 The question of what constitutes an 'optimal' tenure for top managers is difficult to answer. A recently published article in Harvard Business Review (2019) suggests that periods of up to 7-9 years may be considered as 'optimal'. The mean value of our top manager cohort's tenure is 9.2 (Table 1) which seems to be at the upper end of this range. However, it has to be considered that our study is based on a German sample of management board members, while HBR data are based on a world sample and the particular function of the CEO.
} 
more qualitative research (for instance, interviews with board members, executive search firms, or active shareholders) may shed light on the nexus between top manager internationality and tenure with a more refined differentiation of tenure endat least for selected cases in which the 'true' reasons are accessible to researchers. Such qualitative research may also study boards over time, to grasp better how interactions between board members evolve and contribute to tenure end (Pye 2004).

Second, we know from previous research in the upper echelons field that top managers may get 'stale in the saddle'. Miller (1991), for instance, revealed that long-tenured CEOs are less likely to match organizations' strategy and structure with challenges posed by the firms' environment. This failure to match strategy and environment hurts financial performance. Hence, this stream of research (e.g., see also Le and Kroll 2017; O'Shannassy and Leenders 2016; Zona 2014) has already made us aware of the fact that serving for a long time on a board can have detrimental consequences at the organizational level. Although we do not answer the question of the 'ideal' length of top managers' tenure in our research, we posit that there is an area of conflict between antecedents of board tenure at the individual level and consequences at the organizational level: for some individuals (who wish to stay as long as possible at a specific firm), it may be desirable to serve for a long time on the board, whereas firms may have reasons to avoid overly long tenure. Prior research has also shown that diversity on the board comes with several beneficial outcomes; hence diversity in terms of tenure may have positive consequences as well (Jebran et al. 2020; Li and Wahid 2018). These arguments mirror Boeker's (1997) findings, which disclosed a negative relationship between upper echelons' board tenure and corporate strategic change. Hence, future research may investigate the consequences of internationality not only at the level of the individual, but also at the level of the firm. In this context, it seems warranted to consider the variety of individual tenures in TMTs and to investigate jointly the influence of internationality for individuallevel, for board-level as well as for firm-level outcomes.

Third, it is self-evident that the relationship between internationality and tenure may also be moderated by additional characteristics and traits of top managers, for which we did not account. One prominent example is the power of board members (for overviews, see, for instance, Finkelstein 1992 or Van Essen et al. 2015), whereby more powerful board members may be in a better position to stay longer on the board, even if they are non-nationals or even if they strongly deviate from the average international work experience of their peers. Hence, it may be a fruitful endeavor for future research to investigate how power (partially) compensates for dissimilarity.

Fourth, in our paper, we opted for interpersonal attraction research and the similarity-attraction paradigm as the main theoretical perspective. We acknowledge that additional theoretical perspectives may be useful to explain shorter tenure of international top managers. As mentioned above, some international top managers (even more than national top managers) are on a boundaryless career track. Hence, these managers may be driven by the desire to have high variety in their career, and hence also the wish not to stay long on one board, but rather sequentially serve on different boards. The boundaryless career approach (Arthur and Rousseau 1996) could therefore serve as an additional theoretical lens for a study such as ours. Likewise, human 
capital theory (Becker 1975) may help us to theorize on the negative relationship between internationality and tenure. Previous studies with a human capital perspective have potentially overestimated the value of foreignness and international work experience for individuals, boards and firms (e.g., Carpenter et al. 2001; Nielsen 2009; Nielsen and Nielsen 2013). In other words: if we assume that, in our context, internationality is less valuable than expected, we can argue that those individuals who have an international background are not reaching longer tenure, as internationality may rather constitute a liability than an asset for them. Hence, the ideas about liability of foreignness which are usually applied at the firm-level (Zaheer 1995) may also be transferred to the level of the individual top manager (with consequences for his or her tenure). Furthermore, literature on diversity management has mostly focused on the positive effects of diversity; this also applies to literature on nationality diversity in the boardroom (for an overview on boardroom diversity, see, Adams et al. 2015; Roberson et al. 2017). However, within literature on diversity management, there are also theoretical approaches which stress the negative impact of diversity on various outcomes. Examples are approaches which focus on cognitive diversity (Kilduff et al. 2000). Miller et al. (1998), for instance, show that differences in executive characteristics such as experiences or expertise may harm strategic decision-making. In sum, we wish to stress that, next to interpersonal attraction research and the similarity-attraction paradigm, additional approaches can be helpful to theorize on the internationality-tenure nexus.

\section{Conclusion}

Our study has implications for both scholars and managers. While many corporate governance codes around the world recommend more diversity, and hence also more international diversity, on corporate boards (see, for instance, ACGPR 2014; GCGC 2017; UKCGC 2016), we show that top managers with foreign nationality and with international work experience which deviates from the norm serve shorter tenures on the management board. Our results are backed-up by interpersonal attraction research and the similarity-attraction paradigm. However, the results question existing claims in practitioner-oriented literature and corporate governance literature, where top managers' international backgrounds are often associated with positive consequences. Given that the benefits of top managers with international background have already been stressed in previous literature (e.g., Carpenter et al. 2001; Nielsen and Nielsen 2013), our study contributes to a balanced understanding of top managers' internationality at the individual level. Foreigners and individuals with high levels of international work experience who aim to serve on management boards (for a long time) are advised to accumulate in-house work experience in the focal firm before being appointed to the management board, as in-house work experience has a direct effect on tenure. 
Acknowledgements The authors would like to thank the reviewers and participants of the 44th EIBA Conference (Poznań 2018) and the AIB 2019 Annual Meeting (Copenhagen 2019) for their valuable comments and suggestions. We also thank Katharina Hefter, Andrea Luber and Lukas Haueter for support and preparatory work related to this paper, in particular for collection of parts of the data. The anonymous reviewers and the editors of this journal are to be acknowledged for their very helpful suggestions for improvement and for their support during the review process.

Funding Open Access funding enabled and organized by Projekt DEAL. This research was supported by a grant from ESCP Business School Research Funding.

\section{Compliance with Ethical Standards}

Conflict of interest The authors declare that they have no competing interests.

Open Access This article is licensed under a Creative Commons Attribution 4.0 International License, which permits use, sharing, adaptation, distribution and reproduction in any medium or format, as long as you give appropriate credit to the original author(s) and the source, provide a link to the Creative Commons licence, and indicate if changes were made. The images or other third party material in this article are included in the article's Creative Commons licence, unless indicated otherwise in a credit line to the material. If material is not included in the article's Creative Commons licence and your intended use is not permitted by statutory regulation or exceeds the permitted use, you will need to obtain permission directly from the copyright holder. To view a copy of this licence, visit http://creativecommons.org/licen ses/by/4.0/.

\section{References}

Abt, M., \& zu Knyphausen-Aufseß, D. (2017). Chief human resources officers on top management teams: An empirical analysis of contingency, institutional, and homophily antecedents. Business Research, $10(1), 49-77$.

ACGPR. (2014). Australian corporate governance principles and recommendations. Sydney: ASX Corporate Governance Council.

Adams, R. B., De Haan, J., Terjesen, S., \& Van Ees, H. (2015). Board diversity: Moving the field forward. Corporate Governance: An International Review, 23(2), 77-82.

Adkins, L. C., \& Hill, R. C. (2011). Using Stata for principles of econometrics. New Jersey: Wiley.

Agrawal, A., Knoeber, C. R., \& Tsoulouhas, T. (2006). Are outsiders handicapped in CEO successions? Journal of Corporate Finance, 12(1), 619-644.

Aiken, L. S., \& West, S. G. (1991). Multiple regression: Testing and interpreting interactions. Newbury Park: Sage Publications.

Allgood, S., \& Farrell, K. A. (2000). The effect of CEO tenure on the relation between firm performance and turnover. The Journal of Financial Research, 23(3), 373-390.

Arthaud-Day, M., Certo, S., Dalton, C., \& Dalton, D. (2006). A changing of the guard: Executive and director turnover following corporate financial restatements. The Academy of Management Journal, 49(6), 1119-1136.

Arthur, M. B., \& Rousseau, D. M. (1996). The boundaryless career: A new employment principle for a new organizational era. New York: Oxford University Press.

Athanassiou, N. A., \& Roth, K. (2006). International experience heterogeneity effects on top management team advice networks: A hierarchical analysis. Management International Review, 46(6), 749-770.

Ballinger, G., \& Marcel, J. (2010). The use of an interim CEO during succession episodes and firm performance. Strategic Management Journal, 31(3), 262-283.

Balsmeier, B., \& Buchwald, A. (2015). Who promotes more innovations? Inside versus outside hired CEOs. Industrial and Corporate Change, 24(5), 1013-1045.

Baruch, Y., Altman, Y., \& Tung, R. L. (2017). Career mobility in a global era: Advances in managing expatriation and repatriation. The Academy of Management Journal, 10(1), 841-889. 
Baruch, Y., Dickmann, M., Altman, Y., \& Bournois, F. (2013). Exploring international work: Types and dimensions of global careers. The International Journal of Human Resource Management, 24(12), 2369-2393.

Baum, C. F. (2009). An introduction to Stata programming. College Station: Stata Press.

Becker, G. S. (1975). Human capital: A theoretical and empirical analysis, with special reference to education. New York: Columbia University Press.

Bernerth, J. B., \& Aguinis, H. (2016). A critical review and best practice recommendations for control variable usage. Personnel Psychology, 69(1), 229-283.

Berns, K., \& Klarner, P. (2017). A review of the CEO succession literature and a future research program. Academy of Management Perspectives, 31(2), 83-108.

Berry, H., Guillén, M. F., \& Zhou, N. (2010). An institutional approach to cross-national distance. Journal of International Business Studies, 41(1), 1460-1480.

Berscheid, E., \& Walster, E. H. (1969). Interpersonal attraction. Reading: Addison-Wesley.

Bidwell, M. (2011). Paying more to get less: The effects of external hiring versus internal mobility. Administrative Science Quarterly, 56(3), 369-407.

Bilgili, T. V., Calderon, C. J., Allen, D. G., \& Kedia, B. L. (2017). Gone with the wind: A meta-analytic review of executive turnover, its antecedents, and post-acquisition performance. Journal of Management, 43(6), 1966-1997.

Blau, P. M. (1960). A theory of social integration. American Journal of Sociology, 65(6), 545-556.

Boeker, W. (1997). Strategic change: The influence of managerial characteristics and organizational growth. The Academy of Management Journal, 40(1), 152-170.

Boone, C., Wezel, F. C., \& Van Witteloostuijn, A. (2006). Top management team composition and organizational ecology: A nested hierarchical selection theory of team reproduction and organizational diversity. In J. A. C. Baum, S. D. Dobrev, \& A. Van Witteloostuijn (Eds.), Ecology and strategy (Advances in Strategic Management) (pp. 103-135). Kidlington: Emerald Group Publishing Limited.

Bowen, H. P., \& Wiersema, M. F. (2004). Modeling limited dependent variables: Methods and guidelines for researchers in strategic management. In D. J. Ketchen \& D. D. Bergh (Eds.), Research methodology in strategy and management (pp. 87-134). Oxford: Elsevier Press.

Bower, J. L. (2007). The CEO within: Why inside outsiders are the key to succession planning. Harvard: Business School Press.

Breen, R., Karlson, K. B., \& Holm, A. (2018). Interpreting and understanding logits, probits, and other nonlinear probability models. Annual Review of Sociology, 44(1), 39-54.

Brickley, J. (2003). Empirical research on CEO turnover and firm-performance: A discussion. Journal of Accounting and Economics, 36(3), 227-233.

Brown, J. A., Anderson, A., Salas, J. M., \& Ward, A. J. (2017). Do investors care about director tenure? Insights from executive cognition and social capital theories. Organization Science, 28(3), 471-494.

Byrne, D. (1971). The attraction paradigm. New York: Academic Press.

Byrne, D. (1997). An overview (and underview) of research and theory within the attraction paradigm. Journal of Social and Personal Relationships, 14(1), 417-431.

Byrne, D., Clore, G. L., Griffitt, W., Lamberth, J., \& Mitchell, H. E. (1973). When research paradigms converge: Confrontation or integration? Journal of Personality and Social Psychology, 28(1), 313-320.

Byrne, D., \& Griffitt, W. (1973). Interpersonal attraction. Annual Review of Psychology, 24(1), 317-336.

Cannella, A. A., \& Monroe, M. J. (1997). Contrasting perspectives on strategic leaders: Toward a more realistic view of top managers. Journal of Management, 23(3), 213-238.

Cannella, A. A., Park, J. H., \& Lee, H. U. (2008). Top management team functional background diversity and firm performance: Examining the roles of team member colocation and environmental uncertainty. The Academy of Management Journal, 51(4), 768-784.

Cannella, A. A., \& Shen, W. (2001). So close and yet so far: Promotion versus exit for CEO heirs apparent. The Academy of Management Journal, 44(2), 252-270.

Cao, J., Ellis, K. M., \& Li, M. (2019). Inside the board room: The influence of nationality and cultural diversity on cross-border merger and acquisition outcomes. Review of Quantitative Finance and Accounting, 53(1), 1031-1068.

Carpenter, M. A., Geletkanycz, M. A., \& Sanders, G. (2004). Upper echelons research revisited: Antecedents, elements, and consequences of top management team composition. Journal of Management, 30(6), 749-778. 
Carpenter, M. A., Sanders, W. G., \& Gregersen, H. B. (2001). Bundling human capital with organizational context: The impact of international assignment experience on multinational firm performance and CEO pay. The Academy of Management Journal, 44(3), 493-511.

Carraher, S. M., Sullivan, S. E., \& Crocitto, M. M. (2008). Mentoring across global boundaries: An empirical examination of home- and host-country mentors on expatriate career outcomes. Journal of International Business Studies, 39(8), 1310-1326.

Chanland, D. E., \& Murphy, W. M. (2018). Propelling diverse leaders to the top: A developmental network approach. Human Resource Management, 57(1), 111-126.

Cho, T. S., \& Hambrick, D. C. (2006). Attention as the mediator between top management team characteristics and strategic change: The case of airline deregulation. Organization Science, 17(4), 453-469.

Chung, K. H., Lubatkin, M., Rogers, R. C., \& Owers, J. E. (1987). Do insiders make better CEOs than outsiders? Academy of Management Executive, 1(3), 323-329.

Clarke, T. (2017). International corporate governance. A comparative approach. New York: Routledge.

Clore, G. L., \& Gormly, J. B. (1974). Knowing, feeling, and liking: A psychophysiological study of attraction. Journal of Research in Personality, 8(1), 218-230.

Cohen, J., Cohen, P., West, S. G., \& Aiken, L. S. (2003). Applied multiple regression/correlation analysis for the behavioral sciences. Mahwah: Lawrence Erlbaum.

Collings, D. G. (2014). Integrating global mobility and global talent management: Exploring the challenges and strategic opportunities. Journal of World Business, 49(2), 253-261.

Collins, C. J., \& Clark, K. D. (2003). Strategic human resource practices, top management team social networks, and firm performance: The role of human resource practices in creating organizational competitive advantage. The Academy of Management Journal, 46(6), 740-751.

Conyon, M. J., \& Florou, A. (2002). Top executive dismissal, ownership and corporate performance. Accounting and Business Research, 32(4), 209-225.

Coughlan, A. T., \& Schmidt, R. M. (1985). Executive compensation, management turnover, and firm performance: An empirical investigation. Journal of Accounting and Economics, 7(13), 43-66.

Cragun, O. R., Nyberg, A. J., \& Wright, P. M. (2016). CEO succession: What we know and where to go? Journal of Organizational Effectiveness: People and Performance, 3(3), 222-264.

Crossland, C., Zyung, J., Hiller, N., \& Hambrick, D. (2014). CEO career variety: Effects on firm-level strategic and social novelty. The Academy of Management Journal, 57(3), 652-674.

Daily, C. M., Certo, S. T., \& Dalton, D. R. (2000). International experience in the executive suite: The path to prosperity? Strategic Management Journal, 21(4), 515-523.

Daily, C. M., \& Dalton, D. R. (1995). CEO and director turnover in failing firms: An illusion of change? Strategic Management Journal, 16(5), 393-400.

Damaraju, N. L., \& Makhija, A. K. (2018). The role of social proximity in professional CEO appointments: Evidence from caste/religion-based hiring of CEOs in India. Strategic Management Journal, 39(1), 2051-2074.

Darlington, R. B. (1990). Regression and linear models. New York: McGraw-Hill.

Datta, D. K., \& Guthrie, J. P. (1994). Executive succession: Organizational antecedents of CEO characteristics. Strategic Management Journal, 15(7), 569-577.

Datta, D. K., \& Rajagopalan, N. (1998). Industry structure and CEO characteristics: An empirical study of succession events. Strategic Management Journal, 19(9), 833-852.

Davidson, W. N., Nemec, C., \& Worrell, D. (2006). Determinants of CEO age at succession. Journal of Management and Governance, 10(1), 35-57.

Davoine, E., \& Ravasi, C. (2013). The relative stability of national career patterns in European top management careers in the age of globalisation: A comparative study in France/Germany/Great Britain and Switzerland. European Management Journal, 31(2), 152-163.

De Fond, M. L., \& Park, C. W. (1999). The effect of competition on CEO turnover. Journal of Accounting and Economics, 27(1), 35-56.

Denis, D. J., \& Denis, D. K. (1995). Firm performance changes following top management dismissals. Journal of Finance, 50(4), 1029-1057.

Dickmann, M. (2017). Expatriate research for and with practitioners. In Y. McNulty \& J. Selmer (Eds.), Research handbook of expatriates (pp. 416-433). Cheltenham: Edward Elgar Publishing.

Die Welt. (2017). Die globale Elite ist alles andere als international. https://www.welt.de/wirtschaft/artic le163920714/Die-globale-Elite-ist-alles-andere-als-international.html. Accessed 30 June 2019. 
Doms, M., \& zu Knyphausen-Aufseß, D. (2014). Structure and characteristics of top management teams as antecedents of outside executive appointments: A three-country study. The International Journal of Human Resource Management, 25(22), 3060-3085.

Dow, D., \& Karunaratna, A. (2006). Developing a multidimensional instrument to measure psychic distance stimuli. Journal of International Business Studies, 37(5), 578-602.

Du Plessis, J. J., Hargovan, A., Bagaric, M., \& Harris, J. (2015). Principles of contemporary corporate governance. Melbourne: Cambridge University Press.

Ebbes, P., Papies, D., \& Van Heerde, H. J. (2016). Dealing with endogeneity: A nontechnical guide for marketing researchers. In C. Homburg, M. Klarmann, \& A. Vomberg (Eds.), Handbook of market research (pp. 1-37). Cham: Springer.

Elsaid, E., \& Ursel, N. D. (2018). Re-examining the glass cliff hypothesis using survival analysis: The case of female CEO tenure. British Journal of Management, 29(1), 156-170.

Fee, C. E., \& Hadlock, C. J. (2004). Management turnover across the corporate hierarchy. Journal of Accounting and Economics, 37(1), 3-38.

Fernandes, N. A., Ferreira, M. A., Matos, P., \& Murphy, K. J. (2013). Are US CEOs paid more? New international evidence. Review of Financial Studies, 26(2), 323-367.

Festinger, L. (1957). A theory of cognitive dissonance. Stanford: Stanford University Press.

Financial Times. (2012). Foreign CEOs face challenges in Japan. https://www.ft.com/content/fb697 4b0-9066-11e1-8cdc-00144feab49a. Accessed 29 June 2019.

Finkelstein, S. (1992). Power in top management teams: Dimensions, measurement, and validation. The Academy of Management Journal, 35(3), 505-538.

Finkelstein, S., Cannella, A. A., \& Hambrick, D. C. (2009). Strategic leadership: Theory and research on executives, top management teams, and boards. New York: Oxford University Press.

Finkelstein, S., \& Hambrick, D. (1990). Top-management-team tenure and organizational outcomes: The moderating role of managerial discretion. Administrative Science Quarterly, 35(3), 484-503.

Fiss, P. C. (2006). Social influence effects and managerial compensation evidence from Germany. Strategic Management Journal, 27(1), 1013-1031.

Fiss, P. C., \& Zajac, E. J. (2004). The diffusion of ideas over contested terrain: The (non) adoption of a shareholder value orientation among German firms. Administrative Science Quarterly, 49(4), 501-534.

Fitness, J., Fletcher, G., \& Overall, N. (2007). Interpersonal attraction and intimate relationships. In M. A. Hogg \& J. Cooper (Eds.), The SAGE Handbook of social psychology (pp. 258-278). London: Sage Publications.

Flickinger, M., Wrage, M., Tuschke, A., \& Bresser, R. (2016). How CEOs protect themselves against dismissal: A social status perspective. Strategic Management Journal, 37(6), 1107-1117.

Fredrickson, J. W., Hambrick, D. C., \& Baumrin, S. (1988). A model of CEO dismissal. Academy of Management Review, 13(2), 255-270.

Froese, F. J., Kim, K., \& Eng, A. (2016). Language, cultural intelligence, and inpatriate turnover intentions: Leveraging values in multinational corporations through inpatriates. Management International Review, 56(2), 283-301.

GCGC. (2017). German Corporate Governance Code. Frankfurt am Main: Government Commission German Corporate Governance Code.

Georgakakis, D., Dauth, T., \& Ruigrok, W. (2016). Too much of a good thing: Does international experience variety accelerate or delay executives' career advancement? Journal of World Business, 51(3), 425-437.

Georgakakis, D., Greve, P., \& Ruigrok, W. (2017). Top management team faultlines and firm performance: Examining the CEO-TMT interface. The Leadership Quarterly, 28(6), 741-758.

Georgakakis, D., Greve, P., \& Ruigrok, W. (2018). Differences that matter: Hiring modes and demographic (dis)similarity in executive selection. The International Journal of Human Resource Management. https://doi.org/10.1080/09585192.2018.1496126.

Georgakakis, D., \& Ruigrok, W. (2017). CEO succession origin and firm performance: A multilevel study. Journal of Management Studies, 54(1), 58-87.

Gjerløv-Juel, P. (2019). Executive turnover. Firms' subsequent performances and the moderating role of organizational characteristics. European Management Journal, 37(6), 794-805.

Godthelp, M., \& Glunk, U. (2003). Turnover at the top: Demographic diversity as a determinant of executive turnover in the Netherlands. European Management Journal, 21(5), 614-625.

Greene, W. (2008). Econometric analysis. New York: Prentice Hall. 
Greve, P., Biemann, T., \& Ruigrok, W. (2015). Foreign executive appointments: A multilevel examination. Journal of World Business, 50(4), 674-686.

Grusky, O. (1963). Managerial succession and organizational effectiveness. American Journal of Sociology, 69(1), 21-31.

Grühn, B., Strese, S., Flatten, T. C., Jaeger, N. A., \& Brettel, M. (2017). Temporal change patterns of entrepreneurial orientation: A longitudinal investigation of CEO successions. Entrepreneurship Theory and Practice, 41(4), 591-619.

Guillaume, Y. R. F., Brodbeck, F. C., \& Riketta, M. (2012). Surface- and deep-level dissimilarity effects on social integration and individual effectiveness related outcomes in work groups: A meta-analytic integration. Journal of Occupational and Organizational Psychology, 85(1), 80-115.

Gupta, A. K. (1984). Contingency linkages between strategy and general manager characteristics: A conceptual examination. Academy of Management Review, 9(3), 399-412.

Hambrick, D. C., Davison, S. C., Snell, S. A., \& Snow, C. C. (1998). When groups consist of multiple nationalities: Towards a new understanding of the implications. Organization Studies, 19(2), 181-205.

Hambrick, D. C., \& Fukutomi, G. D. S. (1991). The seasons of a CEO's tenure. Academy of Management Review, 16(4), 719-742.

Hambrick, D. C., \& Mason, P. A. (1984). Upper echelons: The organization as a reflection of its top managers. Academy of Management Review, 9(2), 193-206.

Hambrick, D. C., \& Quigley, T. J. (2014). Toward more accurate contextualization of the CEO effect on firm performance. Strategic Management Journal, 35(4), 473-491.

Hamori, M., \& Kakarika, M. (2009). External labor market strategy and career success: CEO careers in Europe and the United States. Human Resource Management, 48(3), 355-378.

Hamori, M., \& Koyuncu, B. (2011). Career advancement in large organizations in Europe and the United States: Do international assignments add value? The International Journal of Human Resource Management, 22(4), 843-862.

Hamori, M., Koyuncu, B., Cao, J., \& Graf, T. (2015). What high-potential young managers want. MIT Sloan Management Review, 57(1), 61-68.

Harris, R. J. (2001). A primer of multivariate statistics. New York: Psychology Press.

Harvard Business Review. (2017). Why CMOs never last and what to do about it. https://hbr.org/2017/07/ the-trouble-with-cmos. Accessed 20 Sep 2019.

Harvard Business Review. (2019). The best-performing CEOs in the world, 2019. https://hbr.org/2019/11/ the-ceo-100-2019-edition. Accessed 5 Mar 2020.

Henderson, A. D., Miller, D., \& Hambrick, D. C. (2006). How quickly do CEOs become obsolete? Industry dynamism, CEO tenure, and company performance. Strategic Management Journal, 27(5), $447-460$.

Herrmann, P., \& Datta, D. K. (2002). CEO successor characteristics and the choice of foreign market entry mode: An empirical study. Journal of International Business Studies, 33(3), 551-569.

Hilger, S., Richter, A., \& Schäffer, U. (2013). Hanging together, together hung? Career implications of interpersonal ties between CEOs and top managers. Business Research, 6(1), 8-32.

Hill, C. W., \& Phan, P. (1991). CEO tenure as a determinant of CEO pay. The Academy of Management Journal, 34(3), 707-717.

Hofstede, G., Hofstede, G. J., \& Minkov, M. (2010). Cultures and organizations-software of the mind: Intercultural cooperation and its importance for survival. New York: McGraw-Hill.

Holgersson, C. (2013). Recruiting managing directors: Doing homosociality. Gender, Work \& Organization, 20(1), 454-466.

Hopt, K. J., \& Leyens, P. C. (2004). Board models in Europe-recent developments of internal corporate governance structures in Germany, the United Kingdom, France, and Italy. European Company and Financial Law Review, 1(2), 135-168.

House, R. J., et al. (2004). Culture, leadership, and organizations. The GLOBE study of 62 societies. London: Sage Publications.

Howell, D. C. (2012). Statistical methods for psychology. Belmont: Cengage Wadsworth.

Huang, S., \& Hilary, G. (2018). Zombie board: Board tenure and firm performance. Journal of Accounting Research, 56(4), 1285-1329.

Hurley, A. E., Fagenson-Eland, E. A., \& Sonnenfeld, J. A. (1997). Does cream always rise to the top? An investigation of career attainment determinants. Organization Dynamics, 26(2), 65-71.

Huson, M. R., Parrino, R., \& Starks, L. T. (2001). Internal monitoring mechanisms and CEO turnover: A long-term perspective. Journal of Finance, 56(6), 2265-2297. 
Hwang, B. H., \& Kim, S. (2009). It pays to have friends. Journal of Financial Economics, 93(1), $138-158$.

Jebran, K., Chen, S., \& Zhang, R. (2020). Board diversity and stock price crash risk. Research in International Business and Finance, 51(1), 1-19.

Jenter, D., \& Kanaan, F. (2015). CEO turnover and relative performance evaluation. Journal of Finance, $70(1), 2155-2183$.

Jiang, F., Ananthram, S., \& Li, J. (2018). Global mindset and entry mode decisions: The moderating roles of managers' decision-making style and managerial experience. Management International Review, 58(3), 413-447.

Jimenez, A., Holmqvist, J., \& Jimenez, D. (2019). Cross-border communication and private participation projects: The role of genealogical language distance. Management International Review, 59(6), 1009-1033.

Kaczmarek, S., Kimino, S., \& Pye, A. (2012). Antecedents of board composition: The role of nomination committees. Corporate Governance: An International Review, 20(1), 474-489.

Kaczmarek, S., \& Ruigrok, W. (2013). In at the deep end of firm internationalization: Nationality diversity on top management teams matters. Management International Review, 53(4), 513-534.

Kaplan, S. N., \& Minton, B. A. (2012). How has CEO turnover changed? International Review of Finance, 12(1), 57-87.

Karaevli, A. (2007). Performance consequences of new CEO 'outsiderness': Moderating effects of preand post-succession contexts. Strategic Management Journal, 28(7), 681-706.

Karaevli, A., \& Zajac, E. J. (2013). When do outsider CEOs generate strategic change? Journal of Management Studies, 50(7), 1267-1294.

Katmon, N., Mohamad, Z. Z., Norwani, N. M., \& Al Farooque, O. (2017). Comprehensive board diversity and quality of corporate social responsibility disclosure: Evidence from an emerging market. Journal of Business Ethics, 157(2), 447-481.

Kedia, B. L., \& Mukherji, A. (1999). Global managers: Developing a mindset for global competitiveness. Journal of World Business, 34(1), 230-251.

Kesner, I. F., \& Sebora, T. C. (1994). Executive succession: Past, present and future. Journal of Management, 20(2), 327-372.

Khanna, T., \& Palepu, K. G. (2004). Globalization and convergence in corporate governance: Evidence from Infosys and the Indian software industry. Journal of International Business Studies, 35(6), 484-507.

Kilduff, M., Angelmar, R., \& Mehra, A. (2000). Top management-team diversity and firm performance: Examining the role of cognitions. Organization Science, 11(1), 21-34.

Kish-Gephart, J. J., \& Campbell, J. T. (2015). You don't forget your roots: The influence of CEO social class background on strategic risk taking. The Academy of Management Journal, 58(6), 1614-1636.

Klohnen, E., \& Luo, S. (2003). Interpersonal attraction and personality: What is attractive self-similarity, ideal similarity, complementarity or attachment security? Journal of Personality and Social Psychology, 85(4), 709-722.

Knight, D., Pearce, C. L., Smith, K. G., Olian, J. D., Sims, H. P., Smith, K. A., \& Flood, P. (1999). Top management team diversity, group process and strategic consensus. Strategic Management Journal, 20(5), 445-465.

Koch, M., Forgues, B., \& Monties, V. (2017). The way to the top: Career patterns of Fortune 100 CEOs. Human Resource Management, 56(2), 267-285.

Köllen, T., Koch, A., \& Hack, A. (2020). Nationalism at work: Introducing the "nationality-based organizational climate inventory" and assessing its impact on the turnover intention of foreign employees. Management International Review, 60(1), 97-122.

Korn Ferry. (2018). Age and tenure in the C-Suite: Korn Ferry Institute reveals trends by title and industry. https://www.kornferry.com/press/age-and-tenure-in-the-c-suite-korn-ferry-institute-study-revea 1s-trends-by-title-and-industry. Accessed 15 Sep 2019.

Kraimer, M., Bolino, M., \& Mead, B. (2016). Themes in expatriate and repatriate research over four decades: What do we know and what do we still need to learn? Annual Review of Organizational Psychology and Organizational Behavior, 3(1), 83-109.

Lau, D. C., \& Murnighan, J. K. (1998). Demographic diversity and faultlines: The compositional dynamics of organizational groups. Academy of Management Review, 23(1), 325-340. 
Lazarsfeld, P., \& Merton, R. (1954). Friendship as a social process: A substantive and methodological analysis. In M. Berger (Ed.), Freedom and control in modern society (pp. 8-66). New York: Van Nostrand.

Le, S., \& Kroll, M. (2017). CEO international experience: Effects on strategic change and firm performance. Journal of International Business Studies, 48(5), 573-595.

Lepak, D. P., \& Snell, S. A. (1999). The human resource architecture: Toward a theory of human capital allocation and development. Academy of Management Review, 24(1), 31-48.

Li, C., Brodbeck, F. C., Shenkar, O., Ponzi, L. J., \& Fisch, J. H. (2017). Embracing the foreign: Cultural attractiveness and international strategy. Strategic Management Journal, 38(4), 950-971.

Li, J., \& Hambrick, D. C. (2005). Factional groups: A new vantage on demographic faultlines, conflict and disintegration in work teams. The Academy of Management Journal, 48(5), 794-813.

Li, N., \& Wahid, A. S. (2018). Director tenure diversity and board monitoring effectiveness. Contemporary Accounting Research, 35(3), 1363-1394.

Liao, T. F. (1994). Interpreting probability models: Logit, probit, and other generalized linear models. Thousand Oaks: Sage Publications.

Lott, A., \& Lott, E. (1965). Group cohesiveness as interpersonal attraction: A review of relationships with antecedent and consequent variables. Psychological Bulletin, 64(1), 259-309.

Lovelace, J. B., Bundy, J. N., Hambrick, D. C., \& Pollock, T. G. (2018). The shackles of CEO celebrity: Sociocognitive and behavioral role constraints on "star" leaders. Academy of Management Review, 43(3), 419-444.

Lydon, J. E., Jamieson, D. W., \& Zanna, M. P. (1988). Interpersonal similarity and the social and intellectual dimensions of first impressions. Social Cognition, 6(1), 269-286.

Main, B. G. M., \& Gregory-Smith, I. (2018). Symbolic management and the glass cliff: Evidence from the boardroom careers of female and male directors. British Journal of Management, 29(1), $136-155$.

Mäkelä, K., Kalla, H. K., \& Piekkari, R. (2007). Interpersonal similarity as a driver of knowledge sharing within multinational corporations. International Business Review, 16(1), 1-22.

Mäkelä, K., \& Suutari, V. (2009). Global careers: A social capital paradox. International Journal of Human Resource Management, 20(5), 992-1008.

Mallin, C. A. (2018). Corporate governance. Oxford: Oxford University Press.

Marcel, J. J., Cowen, A. P., \& Ballinger, G. A. (2017). Are disruptive CEO successions viewed as a governance lapse? Evidence from board turnover. Journal of Management, 43(5), 1313-1334.

McCroskey, J. C., Hamilton, P. R., \& Weiner, A. N. (1974). The effect of interaction behavior on source credibility, homophily, and interpersonal attraction. Human Communication Research, 1(1), 42-52.

McDonald, M. L., Keeves, G. D., \& Westphal, J. D. (2018). One step forward, one step back: White male top manager organizational identification and helping behavior toward other executives following the appointment of a female or racial minority CEO. The Academy of Management Journal, 61(2), 405-439.

McEvoy, G. M., \& Buller, P. F. (2013). Research for practice: The management of expatriates. Thunderbird International Business Review, 55(2), 213-226.

McNulty, Y., \& De Cieri, H. (2011). Global mobility in the 21st century. Conceptualising expatriate return on investment in global firms. Management International Review, 51(6), 897-919.

McPherson, M., Smith-Lovin, L., \& Cook, J. M. (2001). Birds of a feather: Homophily in social networks. Annual Review of Sociology, 27(1), 415-444.

Menz, M. (2012). Functional top management team members: A review, synthesis and research agenda. Journal of Management, 38(1), 45-80.

Meyer, K., van Witteloostuijn, A., \& Beugelsdijk, S. (2017). What's in a p? Reassessing best practices for conducting and reporting hypothesis-testing research. Journal of International Business Studies, 48(5), 535-551.

Michailova, S., Piekkari, R., Storgaard, M., \& Tienari, J. (2017). Rethinking ethnocentrism in international business research. Global Strategy Journal, 7(1), 335-353.

Mietzner, M., Schiereck, D., \& Sohler, J. A. (2017). Einflussfaktoren auf die Amtsdauer von Vorstandsvorsitzenden in börsennotierten Kapitalgesellschaften. Betriebswirtschaftliche Forschung und Praxis, 69(5), 614-632.

Miller, C. C., Burke, L. M., \& Glick, W. H. (1998). Cognitive diversity among upper-echelon executives: Implications for strategic decision processes. Strategic Management Journal, 19(1), 39-58.

Miller, D. (1991). Stale in the saddle: CEO tenure and the match between organization and environment. Management Science, 37(1), 34-52. 
Milliken, F. J., \& Martins, L. L. (1996). Searching for common threads: Understanding the multiple effects of diversity in organizational groups. Academy of Management Review, 21(2), 402-433.

Mobbs, S. (2013). CEOs under fire: The effects of competition from inside directors on forced CEO turnover and CEO compensation. Journal of Financial and Quantitative Analysis, 48(3), 669-698.

Monks, M. A. G., \& Minow, N. (2011). Corporate governance. Chichester: Wiley-Blackwell.

Montoya, M. R., \& Horton, R. S. (2012). A meta-analytic investigation of the processes underlying the similarity-attraction effect. Journal of Personal and Social Relationships, 30(1), 64-94.

Murnieks, C. Y., Haynie, J. M., Wiltbank, R. E., \& Harting, T. (2011). I like how you think: Similarity as an interaction bias in the investor-entrepreneur dyad. Journal of Management Studies, 48(7), 1533-1561.

Murphy, K. J. (1999). Executive compensation. In O. Ashenfelter \& D. Card (Eds.), Handbook of labor economics (pp. 2485-2563). Amsterdam: Elsevier.

Nadler, M. B. (2016). CEO succession: An owner's guide for directors. In B. Le Blanc (Ed.), The handbook of board governance: A comprehensive guide for public, private, and not-for-profit board members (pp. 120-140). New Jersey: Wiley.

Nielsen, B. B., \& Nielsen, S. (2011). The role of top management team international orientation in international strategic decision-making: The choice of foreign entry mode. Journal of World Business, 46(1), 185-193.

Nielsen, B. B., \& Nielsen, S. (2013). Top management team nationality diversity and firm performance: A multilevel study. Strategic Management Journal, 34(3), 373-382.

Nielsen, S. (2009). Why do top management teams look the way they do? A multilevel exploration of the antecedents of TMT heterogeneity. Strategic Organization, 7(3), 277-305.

Nielsen, S. (2010). Top management team internationalisation and firm performance: The mediating role of foreign market entry. Management International Review, 50(2), 185-206.

Nielsen, S., \& Nielsen, B. B. (2010). Why do firms employ foreigners in their top management team? An exploration of strategic fit, human capital and attraction-selection-attrition perspectives. International Journal of Cross Cultural Management, 10(2), 195-209.

Oehmichen, J., Schult, A., \& Wolff, M. (2017). Keeping their cards close to their chests: How nondelegating CEOs avoid forced career ends. Human Resource Management, 56(2), 225-242.

Oesterle, M.-J. (1999). Führungswechsel im Top-Management: Grundlagen-Wirkungen-Gestaltungsoptionen. Wiesbaden: Gabler.

Oesterle, M.-J., Elosge, C., \& Elosge, L. (2016). Me, myself and I: The role of narcissism in internationalization decisions. International Business Review, 25(5), 1114-1123.

O'Reilly, C., Caldwell, D., \& Barnett, W. (1989). Work group demography, social integration, and turnover. Administrative Science Quarterly, 34(1), 21-37.

O'Shannassy, T., \& Leenders, A. A. M. (2016). Avoiding the 'too comfortable in the saddle' syndrome: Obtaining high performance from the chairperson, CEO and inside directors. Journal of Business Research, 69(12), 5972-5982.

Ou, A. Y., Seo, J., Choi, D., \& Hom, P. W. (2017). When can humble top executives retain middle managers? The moderating role of top management team faultlines. The Academy of Management Journal, 60(5), 1915-1931.

Oxelheim, L., Gregoric, A., Randøy, T., \& Thomsen, S. (2013). On the internationalization of corporate boards: The case of Nordic firms. Journal of International Business Studies, 44(3), 173-194.

Papies, D., Ebbes, P., \& Van Heerde, H. J., et al. (2017). Addressing endogeneity in marketing models. In P. S. Leeflang (Ed.), Advanced methods in modeling markets (pp. 581-627). Cham: Springer.

Peng, M. W., Sun, L. S., \& Markoczy, L. (2015). Human capital and CEO compensation during institutional transitions. Journal of Management Studies, 52(1), 117-147.

Piaskowska, D., \& Trojanowski, G. (2014). Twice as smart? The importance of managers' formativeyears' international experience for their international orientation and foreign acquisition decisions. British Journal of Management, 25(1), 40-57.

Piekkari, R., Oxelheim, L., \& Randøy, T. (2015). The silent board: How language diversity may influence the work processes of corporate boards. Corporate Governance: An international Review, $23(1), 25-41$.

Pye, A. (2004). The importance of context and time for understanding board behavior: Some lessons from social capital research. International Studies of Management and Organization, 34(2), 63-89. 
Reeb, D., Sakakibara, M., \& Mahmood, I. (2012). From the editors: Endogeneity in international business research. Journal of International Business Studies, 43(3), 211-218.

Reiche, B. S. (2009). To quit or not to quit: Organizational determinants of voluntary turnover in MNC subsidiaries in Singapore. The International Journal of Human Resource Management, 20(6), 1362-1380.

Richard, O. C., Wu, J., Markoczy, L. A., \& Chung, Y. (2019). Top management team demographic-faultline strength and strategic change: What role does environmental dynamism play? Strategic Management Journal, 40(1), 987-1009.

Roberson, Q., Holmes, O., \& Perry, J. L. (2017). Transforming research on diversity and firm performance: A dynamic capabilities perspective. Academy of Management Annals, 11(1), 189-216.

Rousseau, D., \& Parks, J. M. (1993). The contracts of individuals and organizations. In L. L. Cummings \& B. M. Staw (Eds.), Research in organizational behavior (pp. 1-43). Greenwich: JAI Press.

Ruigrok, W., Georgakakis, D., \& Greve, P. (2013). Regionalization strategy and performance: The moderating role of industry dynamism and top management team diversity. Multinational Business Review, 21(1), 6-24.

Schepker, D. J., \& Barker, V. L. (2018). How stigmatized are dismissed chief executives? The role of character questioning causal accounts and executive capital in dismissed CEO reemployment. Strategic Management Journal, 39(9), 2566-2586.

Schmid, S., \& Altfeld, F. (2018). International work experience and compensation: Is more always better for CFOs? European Management Journal, 36(4), 530-543.

Schmid, S., \& Dauth, T. (2012). Internationale Diversität im Top-Management-eine empirische Analyse der DAX-30 Unternehmen. Schmalenbachs Zeitschrift für betriebswirtschaftliche Forschung, 64(7), 772-802.

Schmid, S., \& Dauth, T. (2014). Does internationalization make a difference? Stock market reaction to announcements of international top executive appointments. Journal of World Business, 49(1), 63-77.

Schmid, S., \& Wurster, D. J. (2017). International work experience: Is it really accelerating the way to the management board of MNCs? International Business Review, 26(1), 991-1008.

Schmid, S., Wurster, D. J., \& Dauth, T. (2015). Internationalisation of upper echelons in different institutional contexts: Top managers in Germany and the UK. European Journal of International Management, 9(4), 510-535.

Schwenk, C. (1993). Management tenure and explanations for success and failure. Omega, 21(4), 449-456.

Shen, W., \& Cannella, A. A. (2002). Power dynamics within top management and their impacts on CEO dismissal followed by inside succession. The Academy of Management Journal, 45(6), 1195-1206.

Shen, W., \& Cannella, A. A. (2003). Will succession planning increase shareholder wealth? Evidence from investor reactions to relay CEO successions. Strategic Management Journal, 24(2), 191-198.

Simsek, Z. (2007). CEO tenure and organizational performance: An intervening model. Strategic Management Journal, 28(6), 653-662.

Simsek, Z., Veiga, J. F., Lubatkin, M., \& Dino, R. N. (2005). Modeling the multilevel determinants of top management team behavioral integration. The Academy of Management Journal, 48(1), 69-84.

Stevenson, W. B., \& Reddin, R. F. (2009). Social capital and social influence on the board of directors. Journal of Management Studies, 46(1), 16-44.

Story, J. S., Barbuto, J. E., Luthans, F., \& Bovaird, J. A. (2014). Meeting the challenges of effective international HRM: Analysis of the antecedents of global mindset. Human Resource Management, 53, $131-155$.

Strategy\&. (2016). CEO succession study. https://www.strategyand.pwc.com/de/studien/ceo-study-findi ngs-australia. Accessed 28 May 2019.

Suutari, V., Tornikoski, C., \& Mäkelä, L. (2012). Career decision making of global careerists. The International Journal of Human Resource Management, 23(16), 3455-3478.

Tenzer, H., Terjesen, S., \& Harzing, A. W. (2017). Language in international business: A review and agenda for future research. Management International Review, 12(1), 815-854.

Thams, Y., Kelley, K., \& Von Glinow, M. A. (2018). Foreigners in the boardroom: The implications of attitudes toward immigration and conservatism in firms' sub-national context. Journal of Business Research, 91(1), 8-18.

The New York Times. (2014). Bringing change to Ferrari team, and then being shown the door. https ://www.nytimes.com/2014/11/29/sports/autoracing/marco-mattiacci-ferrari.html. Accessed 1 Sep 2019. 
Thomsen, S., \& Conyon, M. (2012). Corporate governance. Mechanisms and systems. Maidenhead: McGraw-Hill.

Tian, J., Haleblian, J., \& Rajagopalan, N. (2011). The effects of board human and social capital on investor reactions to new CEO selection. Strategic Management Journal, 32(7), 731-747.

Torchia, M., Calabrò, A., \& Morner, M. (2015). Board of directors' diversity, creativity, and cognitive conflict. International Studies of Management and Organization, 45(1), 6-24.

Tröster, C., \& Van Knippenberg, D. (2012). Leader openness, nationality dissimilarity, and voice in multinational management teams. Journal of International Business Studies, 43(1), 591-613.

Tsui, A. S., \& O'Reilly, C. A. (1989). Beyond simple demographic effects: The importance of relational demography in superior subordinate dyads. The Academy of Management Journal, 32(2), 402-423.

Tuschke, A., Sanders, W. G., \& Hernandez, E. (2014). Whose experience matters in the boardroom? The effects of experiential and vicarious learning on emerging market entry. Strategic Management Journal, 35(1), 398-418.

UKCGC. (2016). The UK Corporate Governance Code. London: Financial Reporting Council.

Van Bakel, M. (2019). It takes two to tango: A review of the empirical research on expatriate-local interactions. The International Journal of Human Resource Management, 30(21), 2993-3025.

Van Essen, M., Otten, J., \& Carberry, E. J. (2015). Assessing managerial power theory: A meta-analytic approach to understanding the determinants of CEO compensation. Journal of Management, 41(1), 164-202.

Van Knippenberg, D., \& Mell, J. N. (2016). Past, present, and potential future of team diversity research: From compositional diversity to emergent diversity. Organizational Behavior and Human Decision Processes, 136(1), 135-146.

Van Peteghem, M., Bruynseels, L., \& Gaeremynck, A. (2018). Beyond diversity: A tale of faultlines and frictions in the board of directors. The Accounting Review, 93(2), 339-367.

Van Veen, K., \& Marsman, I. (2008). How international are executive boards of European MNCs? Nationality diversity in 15 European countries. European Management Journal, 26(3), 188-198.

Van Veen, K., Sahib, P. R., \& Aangeenbrug, E. (2014). Where do international board members come from? Country-level antecedents of international board member selection in European boards. International Business Review, 23(2), 407-417.

Van Vianen, A. E. M., Rosenauer, D., Homan, A. C., Horstmeier, C. A. L., \& Voelpel, S. C. (2018). Career mentoring in context: A multilevel study on differentiated career mentoring and career mentoring climate. Human Resource Management, 57(1), 583-599.

Veltrop, D. B., Molleman, E., Hooghiemstra, R., \& Van Ees, H. (2018). The relationship between tenure and outside director task involvement: A social identity perspective. Journal of Management, 44(2), 445-469.

Wagner, W., Pfeffer, J., \& O’Reilly, C. (1984). Organizational demography and turnover in top-management groups. Administrative Science Quarterly, 29(1), 74-92.

Wang, M., \& Wanberg, C. (2017). 100 years of applied psychology research on individual careers: From career management to retirement. Journal of Applied Psychology, 102(3), 546-563.

Ward, A., Sonnenfeld, J. A., \& Kimberly, J. R. (1995). In search of a kingdom: Determinants of subsequent career outcomes for chief executives who are fired. Human Resource Management, 34(1), $117-139$.

West, J., \& Graham, L. (2004). A linguistic-based measure of cultural distance and its relationship to managerial values. Management International Review, 44(3), 239-260.

Westphal, J. D. (1999). Collaboration in the boardroom: Behavioral and performance consequences of CEO-board social ties. The Academy of Management Journal, 42(1), 7-24.

Westphal, J. D., \& Milton, L. P. (2000). How experience and network ties affect the influence of demographic minorities on corporate boards. Administrative Science Quarterly, 45(2), 366-398.

Westphal, J. D., \& Zajac, E. (1995). Who shall govern? CEO/board power, demographic similarity, and new director selection. Administrative Science Quarterly, 40(1), 60-83.

Wiersema, M. F., \& Bantel, K. (1992). Top management team demography and corporate strategic change. The Academy of Management Journal, 35(1), 91-121.

Yeganeh, H. (2014). A weighted, Mahalanobian, and asymmetrical approach to calculating national cultural distance. Journal of International Management, 20(1), 436-463.

Zaheer, S. (1995). Overcoming the liability of foreignness. The Academy of Management Journal, 38(2), 341-363.

Zajac, E. T., \& Westphal, J. D. (1995). Accounting for the explanations of CEO compensation: Substance and symbolism. Administrative Science Quarterly, 40(2), 283-308. 
Zajac, E. T., \& Westphal, J. D. (1996). Who shall succeed? How CEO/board preferences and power affect the choice of new CEOs. The Academy of Management Journal, 39(1), 64-90.

Zhang, Y. (2008). Information asymmetry and the dismissal of newly appointed CEOs: An empirical investigation. Strategic Management Journal, 29(8), 859-872.

Zhu, D. H., \& Westphal, J. D. (2014). How directors' prior experience with other demographically similar CEOs affects their appointments to corporate boards and the consequences for CEO compensation. The Academy of Management Journal, 57(3), 791-813.

Zona, F. (2014). Board leadership structure and diversity over CEO time in office: A test of the evolutionary perspective on Italian firms. European Management Journal, 32(4), 672-681.

Publisher's Note Springer Nature remains neutral with regard to jurisdictional claims in published maps and institutional affiliations. 